\title{
Corroded by Globalisation: The Image of Japanese Literature in German Review Articles
}

\author{
Erich Havranek
}

\begin{abstract}
The end of the 1980s was marked by a general interest in Japan because of the country's ongoing economic boom. Shortly after, in 1990, Japan was guest of honour at the Frankfurt Book Fair and, in 1994, Ōe Kenzaburō was awarded the Nobel Prize in Literature. All of this led to the establishment of a good number of Japanese literature series being published in German-speaking countries and a considerable increase in the translation of Japanese literature. Furthermore, the dispute over a novel by Murakami Haruki on the TV show Das Literarische Quartett (The Literary Quartet) in the year 2000 had a remarkable influence on these developments. This dispute triggered the tremendous popularity of the author in German-speaking countries and simultaneously led to a change of attitude towards the translation of Japanese works in publishing houses. Against this backdrop, this paper investigates the image of Japanese literature portrayed in review articles of German language newspapers at the beginning of the 21st century. The main themes of these review articles will be presented in 12 categories that constitute the image of Japanese literature in the German book market. These categories will be presented and described in detail before conclusions about the tendencies of reviewing Japanese literature and about what influence these tendencies have on the image of Japanese literature are drawn.
\end{abstract}

Keywords: Japanese literature, German book market, reception, image, reviews

prae sens
Havranek, Erich. "Corroded by Globalisation: The Image of Japanese Literature in German Review Articles." In Vienna Journal of East Asian Studies, Volume 6, eds. Rudiger Frank, Ina Hein, Lukas Pokorny and Agnes Schick-Chen. Vienna: Prae-sens Verlag, 2014, pp. 125-158. https:/doi.org/10.2478/vjeas-2014-0010 


\section{Introduction}

Japanese literature is in a difficult position in the German book market. The language, the writing system, and many unfamiliar cultural concepts make it a very challenging task to introduce a Japanese literary work to foreign readers. Yet, the foreignness of Japanese culture generates a certain interest in its literature among the reading public of German-speaking countries. Still, Japanese literature, in order to be recognised, needs the help of intermediaries, promoters, sponsors, and chance.

There is no other explanation than chance for the tensions that erupted between two presenters of the literature TV show Das Literarische Quartett (The Literary Quartet) following a heated discussion about the translation of the novel Kokkyō no minami, taiyō no nishi 国境の南, 太陽の西 (German: Gefährliche Geliebte) by the then relatively unknown author within Germany Murakami Haruki 村上春樹 (b. 1949). The argument was about the style of the work, which was unacceptable for one presenter, but only a minor matter in an otherwise brilliant novel for the other. Murakami received a lot of publicity following the controversy and it drew attention to contemporary Japanese literature as well as to the role of translators.

In a previous paper I focused on programmes, projects, and persons supporting Japanese literature in the German book market (see Havranek 2010). In this paper I am going to present the image of Japanese literature among exemplary readers, that is, reviewers of German newspapers in the early 2000s. In 1994, Irmela HijiyaKirschnereit concluded that since the 1970s Japanese literature reviewers' focus on cultural differences began to decline (1996: 709) and move away from a level of expectation that was mainly informed by translations of the works of four authors: Kawabata Yasunari 川端康成 (1899-1972), Mishima Yukio 三島由紀夫 (192570), Akutagawa Ryūnosuke 芥川龍之介 (1892-1927), and Inoue Yasushi 井上靖 (1907-91) (ibid.: 703). This process of moving away from a stereotypical practice of reviewing Japanese literature was still ongoing in the 1990s and was also influenced by the role of the English language in literary translations from Japanese to German: English translations were often used to check against German translations and sometimes even as source for German translations of literature originally produced in Japanese (ibid.: 709-710). This practice of translating Japanese literature via an English translation into German, however, changed after the Murakami controversy and has almost disappeared in the contemporary period. Based upon these considerations, I will investigate the image of Japanese literature depicted by reviewers of German newspapers following the Murakami controversy.

For this purpose, I selected review articles of translations of Japanese literary works that were published between 2003 and 2008 in German newspapers. This period starts long enough after the Murakami controversy for it to have had an effect on the book market and offers a manageable amount of articles. The criteria for selection were that the article had to deal with one or more recent books of an author 
and the book was under central consideration in the article. Furthermore, the articles had to be available at the Innsbrucker Zeitungsarchiv, an archive that collects articles about literature from a wide range of German periodicals. In the end, there were 200 review articles for 58 works by 30 authors. ${ }^{1}$

The following aspects of the articles were analysed:

- Statements about authors

- Comparisons between authors

- Statements about the style of an author or text

- Statements about the themes explored by an author or within a text

- Statements that connect the style and the themes with Japan

- Statements about the distinctive Japanese features of an author or text

- General statements about style and themes of Japanese literature

'Style' here is simply defined as 'how an author writes' and 'theme' as 'about what an author writes'. Upon marking these various statements in the articles the following categories could be deduced: presentation of the authors; globalisation and EastWest conflict; obscurity; superficiality; the metropolis and loneliness; violence; feminism; harmony and the calm stream of language; esotericism and transience; reality and fantasy; genres; mistakes. These categories are the main aspects of the German image of Japanese literature, painted in review articles of German newspapers. They will be described in detail further below, but first I offer a brief review of the situation of Japanese literature in the German book market.

\section{Conveying Japanese literature}

Between 1988 and 1994 the amount of translations from Japanese to German rose by 54.7 percent compared to the number of translations published from 1868 to 1987 (Ogasa, Puls, and Stalph 1995: xii). This can be attributed to the wide interest in Japan due to the country's ongoing economic boom by the end of the 1980s. Shortly after, in 1990, Japan was guest of honour at the Frankfurt Book Fair and, in 1994, Ōe Kenzaburō 大江健三郎 (b. 1935) was awarded the Nobel Prize in Literature. All of this led to the establishment of a good number of Japanese literature publish-

1 For a full list of review articles, the authors, and their works reviewed in the articles see Primary Sources: Review Articles and Reviewed Works in the References section. 
ing series in German-speaking countries and a considerable increase in translations of Japanese literature. Examples of publishing series include Japanische Bibliothek (Japanese Library) (1989-2000) edited by Hijiya-Kirschnereit for Insel Publishing and Japan Edition founded in 1992 by Jürgen Berndt at Quintessenz Publishing and continued from 1994 on by editor Eduard Klopfenstein and since 2004 published by Be.bra Publishing.

The importance of the author Murakami from the year 2000 on cannot be underestimated. Judith Schmuck presented a M.A. thesis in 2005 investigating the German reception of Murakami in detail (2005). One aspect, however, in the history of the reception of the author's works deserves attention here because it involves the introduction of the author to the wider public. It was the controversy sparked by the heated discussion about the novel Gefährliche Geliebte in the literary TV show Das Literarische Quartett. Siegrid Löffler, one of the presenters, characterised the style of Murakami as 'literarisches Fastfood' (literary fast food) and took offence at the explicit sex scenes. Marcel Reich-Ranicki, another one of the presenters, defended the novel and attacked Löffler personally. The TV show was soon afterwards discontinued, but more important was that it raised questions about the practice of translating Japanese authors from the English version to German. This was the case with Gefährliche Geliebte and the Japanologist Herbert Worm showed that this in part caused the criticism of Murakami's style (2000). From this time on, however, Murakami became the best-selling Japanese author in Germany.

An overview of the situation of Japanese literature in the German book market at the beginning of the 2000s is presented in the table below. For comparison, the two most important source languages of translations in the German book market, as well as two other East Asian languages, are included.

Table 1 Number of translations into German by source languages and percentage of the total number of translations

\begin{tabular}{|l|l|l|l|l|l|}
\hline Year & Japanese & English & French & Korean & Chinese \\
\hline 1999 & $72(0.9 \%)$ & $5461(71.9 \%)$ & $816(10.7 \%)$ & - & $13(0.2 \%)$ \\
\hline 2000 & $51(0.7 \%)$ & $5519(72.3 \%)$ & $730(9.6 \%)$ & - & $18(0.2 \%)$ \\
\hline 2001 & $124(1.3 \%)$ & $6924(74.1 \%)$ & $821(8.8 \%)$ & - & $12(0.1 \%)$ \\
\hline 2002 & $23(0.4 \%)$ & $3782(70.0 \%)$ & $548(10.1 \%)$ & - & - \\
\hline 2003 & $33(0.4 \%)$ & $3732(49.3 \%)$ & $586(7.7 \%)$ & - & $9(0.1 \%)$ \\
\hline 2004 & $87(1.6 \%)$ & $3073(56.8 \%)$ & $543(10 \%)$ & $10(0.2 \%)$ & - \\
\hline
\end{tabular}




\begin{tabular}{|l|l|l|l|l|l|}
\hline 2005 & $35(0.6 \%)$ & $3691(60.2 \%)$ & $575(9.4 \%)$ & $31(0.5 \%)$ & $31(0.5 \%)$ \\
\hline 2006 & $52(0.9 \%)$ & $3785(65.6 \%)$ & $579(10 \%)$ & - & $14(0.2 \%)$ \\
\hline 2007 & $52(0.8 \%)$ & $4130(67.1 \%)$ & $603(9.8 \%)$ & - & $19(0.3 \%)$ \\
\hline 2008 & $105(1.4 \%)$ & $4908(66.9 \%)$ & $847(11.5 \%)$ & - & $28(0.4 \%)$ \\
\hline
\end{tabular}

Source: BBZ 2000, 2001, 2002, 2003, 2004, 2005, 2006, 2007, 2008, 2009

Until 1999, Japanese literature never had a higher share than 0.5 percent of all translations. The year 1999, however, marks a noteworthy change with a record high of 0.9 percent. Although there was a drop in 2002 and 2003, there were other peaks in 2001, 2004, and 2008, and after 2003 the share was never below 0.4 percent.

Though these figures are mainly due to best-selling authors like Murakami, there were numerous smaller initiatives to present Japanese authors to a German-reading audience like the aforementioned publishing series. These initiatives are often not self-sustainable and are therefore dependent on support. The two most important institutions which offered support were the Agency for Cultural Affairs (Bunka-chō 文化庁) and the Japan Foundation (Kokusai kōryū kikin 国際交流基金). The Agency for Cultural Affairs operated the Japanese Literature Publishing Project (JLPP), which granted funds for the translation and publication of selected Japanese authors in foreign languages. The Japan Foundation also supports the publication of works that have a thematic relation to Japan and aids the publishing houses representing Japan at international book fairs.

Whether it is best sellers or small projects, translators always play a very important part in the reception of a foreign-language author. As the Murakami controversy shows, the status of authors in a foreign book market is closely tied to the work of translators. Their work does not only have an impact on individual authors but also on the image of the literature of a nation. Therefore their role is also essential in the process of conveying literature of different languages to the book market they are working in.

\section{Image of Japanese literature in Germany}

\section{Overview}

I have analysed 200 review articles for 58 works of 30 authors. Most articles (29) were published in the Neue Zürcher Zeitung (NZZ) followed by the Frankfurter Allgemeine Zeitung (FAZ) with 28 and the Zeit with 19 articles. The remaining newspapers that published ten or more reviews are Süddeutsche Zeitung (SZ) (13), 
Welt (11), and die tageszeitung (taz) (10). There are four Austrian newspapers which published six articles each: Wiener Zeitung, Der Standard, Salzburger Nachrichten, and Tiroler Tageszeitung.

By taking a closer look at individual years it becomes apparent that in the beginning of the period under investigation $F A Z$ published the most review articles (seven in 2003; six in 2004). In 2005, Zeit printed the most reviews with seven articles and from 2006 on NZZ took the lead (five in 2006; five in 2007; nine in 2008). Considering that these newspapers published the most review articles of Japanese literature in the period between 1988 and 1994 (Giacomuzzi-Putz 1996: 163), it is safe to say that NZZ, FAZ, and Zeit have been the most important print media outlets for the discussion of Japanese literary works for more than 20 years.

In 2004, 40 review articles were published. Afterwards there seemed to be a continuing downward trend. In 2007 only 19 reviews were published. However, this development came to an end when in 2008 the number of reviews again rose to 39. The number of reviews often depends on a few spectacular new releases and does not express a steady interest in Japanese literature. In 2008, 32 reviews were about only four authors: Kawakami Hiromi 川上弘美 (b. 1958) (11), Murakami (11), Ōe (6), and Ōsawa Arimasa 大沢在昌 (b. 1956) (4). In that year, 22 reviews of the 39 published were about two works: Der Himmel ist blau, die Erde ist weiß (Sensei no kaban センセイの鞄) by Kawakami and Wovon ich rede, wenn ich vom Laufen rede (Hashiru koto ni tsuite kataru toki ni boku no kataru koto 走ることについて 語るときに僕の語ること) by Murakami.

As reviewers, editors prefer experts of literature in general and not of area studies because area studies experts tend to see themselves as lobbyists of a certain culture (Spiegel 2001: 94). An overview of the most important reviewers confirms this preference. The following six persons each wrote more than five of the reviews published between 2003 and 2008: Ludger Lütkehaus (15), Steffen Gnam (13), Hijiya-Kirschnereit (9), Ulrich Baron (8), Leopold Federmair (7), and Susanne Messmer (6). Of these only Hijiya-Kirschnereit is a distinguished expert of Japanese studies and Japanese literature.

The most reviews were written about Murakami, Ōe, Yoshimoto Banana よしも とばなな (b. 1964), Ogawa Yōko 小川洋子 (b. 1962), and Kawakami. Therefore, it can be concluded that the articles focus on successful, established authors who are still active. There is a slight shift towards the review of younger authors compared to the beginning of the 1990s. Then, the most reviews were written about works of Yoshimoto, Endō Shūsaku 遠藤周作 (1923-1996), Abe Kōbō 安部公房 (19241993), Kawabata, and Murakami (Giacomuzzi-Putz 1996: 158).

There are 80 reviews covering 14 different works of Murakami. These are by far the most for one author. Furthermore, his novel Kafka am Strand (Umibe no Kafuka 海辺のカフカ) was the most reviewed work with 19 articles. Afterwards, however, 
the interest in Murakami seemed to cool somewhat. Though his following novel, Afterdark (Afutā Dāku アフターダーク), was eagerly anticipated and reviewed in 14 articles, it received mostly negative reviews. There was no new release from Murakami in 2007, which had an obvious effect on the total number of reviews of Japanese literature, reaching a low-point in that year. In 2008, there were again 11 reviews: one each for two collections of stories (Wie ich eines schönen Morgens im April das 100\%ige Mädchen sah, ${ }^{2}$ Der Elefant verschwindet ${ }^{3}$ ) and nine for Wovon ich rede, wenn ich vom Laufen rede.

Four works of Ōe received 24 reviews and hence the second most. There were 13 of these that addressed Tagame: Berlin-Tōkyō (Torikaeko/Chenjiringu 取り替え子/ チェンジリング) which attracted attention because of its biographic nature. The novel has been described as a roman à clef with the character Goro being the film director and Ōe's friend Itami Jūzō 伊丹十三 and the protagonist Kogito being Ōe himself. The high number of reviews, however, is also connected with the 70th birthday of the author in 2005, the year when Tagame was published. Ōe is still a very respected author but the number of critical articles is growing. In an earlier review, Hijiya-Kirschnereit described his language as difficult and convoluted, abstract and full of metaphors, his themes as dark and tortured almost to the point where it becomes painful for the readers (2001: 50). The main criticism, however, is that the author was excessively egocentric (Hijiya-Kirschnereit 2008b: 11). Other reviewers often assessed his works as too difficult to understand, which will be elaborated below under the section 'Obscurity'.

Works of Yoshimoto were reviewed in 17 articles. From 2005 on, however, she became less important in the German book market. There were still six reviews of two publications in 2005 but none in 2006 and 2008 while in 2007 two works were each reviewed once: the volume of stories Eidechse (Tokage とかげ) and the novel Federkleid (Hagoromo ハゴロモ). Most of the reviewers point out how famous the author is, but at the same time raise doubts about the quality of her later works.

Ogawa enjoyed a good reputation in the early 2000s. Every year since 2001 a new work of the author was published in German. Much acclaimed was the collection of stories Schwimmbad im Regen ("Yūgure no kyūshokushitsu to ame no pūru" 夕暮れの給食室と雨のプール $)^{4}$ which was reviewed four times. The book also

2 This collection of stories has been compiled for the German language book market. The title refers to one of the stories in the collection, "Shigatsu no aru hareta asa ni 100-pāsento no onna no ko ni deau koto ni tsuite”四月のある晴れた朝に 100 パーセントの女の子に出会うことについて (On Seeing the $100 \%$ Perfect Girl One Beautiful April Morning) first published in July 1981 in the magazine Torefuruトレフル (Trefoil).

3 The title refers to one of the stories in the collection, Zō no shōmetsu 象の消滅 (The Elephant Vanishes) first published in August 1985 in the magazine Bungakukai 文學界 (Literary World). Although there is a Japanese collection of stories with the same title (Zō no shōmetsu), there are different stories compiled in it.

4 The Japanese collection of the same stories is named after one of the other stories in this collection: Ninshin-karendā 妊娠カレンダー (German: “Tagebuch einer Schwangerschaft”). 
gained attention because the Japan Foundation awarded the translators, Ursula Gräfe and Kimiko Nakayama-Ziegler, the prize for best translation of the year 2003 for this work.

The big success story of 2008 was Kawakami. Her German debut Der Himmel ist blau, die Erde wei $\beta$ received 11 reviews. These were predominantly positive and none was explicitly negative. Furthermore, Die Umarmung des Todes (Out [=Auto] アウト) by Kirino Natsuo 桐野夏生 (b. 1951) deserves mention which was reviewed seven times and mostly praised enthusiastically.

The mentioned authors gained the most reviews and, therefore, occupy a dominant position in the market in that period. Much less attention was paid to famous authors whose works are considered 'modern classics' like those of Inoue, Akutagawa, or Tanizaki Jun’ichirō 谷崎潤一郎 (1886-1965) and who were still very important in the German literature of the 1990s. For Inoue's 100th birthday, Der Tod des Teemeisters (Honkakubō-ibun 本覚坊遺文) was published for the first time in German in 2007, which was reviewed six times.

The following chapter will analyse the description of Japanese literary works in German reviews. The emphasis will be on similarities and repeatedly mentioned aspects by different reviewers that are attributed to different Japanese authors. Patterns forming the German image of Japanese literature are deduced and are reflected in the names of the categories under consideration.

\section{Aspects of Japanese literature in German review articles}

\section{Presentation of the authors}

Biographical details of the authors are mostly interspersed casually in the articles or left out entirely. However, often there are allusions to the importance of an author in Japan (Messmer 2007b: vi; Hijiya-Kirschnereit 2007: 38; Gnam 2007b: 34; Schoettli 2003: 35), thereby generating interest and justifying the article about the work under consideration. The importance for foreign readers, though, is often determined by how much insight into Japan an author offers (Lütkehaus 2008f: 29, 2008b: 27).

When authors are presented they are often placed within a literary current, usually postmodernism. Murakami is sometimes compared to Paul Auster (Stüttgen 2003: 18; Detje 2005: 16) and the postmodernist characteristics of his works are criticised because of the arbitrariness often associated with postmodernism (Gauss 2004: 48). Nevertheless, the term 'postmodernism' is used neutrally when applied to other authors such as Ogawa (Gnam 2004b: 38), Yoshimoto (Messmer 2004b: 17), or Tsutsui Yasutaka 筒井康隆 (b. 1934) (Hijiya-Kirschnereit 2007: 38). For Ōe the term is used as proof that the author and his style are already outmoded (Schulz 2003: 34). 
Overall the presentations of the authors in the reviews are neutral and no certain image of a Japanese author materialises. Murakami and Ōe are exceptions because of the high number of articles devoted to them. Murakami is sometimes used as a measure for less-known authors (Messmer 2005: 17, 2007a: 15) and his relationship to US-American culture is often highlighted (Körte 2003: 8; Albath 2006: 14; Hijiya-Kirschnereit 2006: 40). Ōe, in contrast, is described as an intellectual with a close connection to European culture, influenced by Western intellectual history because of his engagement in Romance studies at the university level (Baron 2005a: $18)$.

\section{Globalisation and East-West conflict}

Especially Murakami is often criticised for his detachment from Japanese culture and the internationality in his themes and settings. Reviewers disapprove of the lack of authenticity and criticise his effort to position himself as an international brand (Form 2003: 10; Körte 2003: 8; Albath 2006: 14). Similar remarks are made about Yoshimoto: she conveyed too little about typical Japanese culture and life. Works that take a critical stance toward globalisation are much more positively reviewed than works that integrate symbols of globalisation naturally (Messmer 2007b: vi). Ikezawa Natsuki 池澤夏樹 (b. 1945) is praised for his vivid tableau of life in the era of globalisation (Hijiya-Kirschnereit 2003a: 34) and Kirino for depicting a violent Japanese society corroded by globalisation (Gohlis 2003: 50).

One important aspect of the complex of globalisation is the clash of Eastern and Western culture. This is something reviewers often seem to expect in a work of Japanese literature, and it is an important issue in the articles (Löhndorf 2003: 35; Dotzauer 2004: 27). It is frequently discussed as a conflict between tradition and modernity. The journey of self-discovery against the background of this conflict between tradition and modernity in the times of transition from old to new values and lifestyles, for example, is seen as the main theme of Uno Chiyo's 宇野千代 (1897-1996) Die Geschichte einer gewissen Frau (Aru hitori no onna no hanashi 或 る一人の女の話) (Lütkehaus 2004a: 48). The subject of Higuchi Ichiyō's 樋口一 葉 (1872-96) stories collected in the book In finsterer Nacht $t^{5}$ is described in similar terms (Gnam 2007b: 34). The conflict is also referred to in a review of Akutagawa's collection of stories Dialoge in der Dunkelheit ${ }^{6}$ (Gnam 2004a: 34). Tellingly, a

5 This collection of stories has been compiled for the German language book market. The title refers to one of the stories in the collection, “Yamiyo"闇(やみ) 夜 (Dark Night) first published from July to November 1894 in the magazine Bungakukai.

6 This too is a collection of texts that has been compiled for the German language book market. The title refers to a fictional dialog in this collection, "Anchū mondō" 闇中問答 (Dialogue in Darkness), published in the year of the author's death, 1927, in the magazine Bungeishunjū 文藝春秋 (Literary Spring and Autumn). 
reviewer is surprised about the missing description of a culture shock in a story written by Ōe where a Japanese character travels to Germany (Thuswaldner 2005: 16).

The influence of Western culture on Japan is often described as a loss of traditions caused by modernisation. On the one hand, works of some authors, like Murakami, are described as a result of this loss, where only a few aspects of traditional Japan can be found. On the other hand, some works are praised for being critical toward Western influence and globalisation as can be seen in the mentioned reviews of the works of Ikezawa or Kirino.

\section{Obscurity}

Works of Japanese literature are often depicted as difficult to understand, and reviewers usually blame the cultural differences between Japan and Europe. One reviewer describes Western readers as excluded from the world of Ōe's Tagame (Tauber 2006: 14). Another one accepts defeat confronted with Ōe's Sayonara, meine Bücher (Sayōnara, watashi no hon yo! さようなら、私の本よ!), as he concedes that the cultural context is simply not transferable (Müller 2008: 16).

Reviewers often hesitate to criticise the obscurity of the texts they are confronted with. They tend to attribute their difficulties in understanding to their insufficient knowledge about Japan and its culture. The complexity can be understood as a glimpse into a mysterious world and can therefore be assessed positively, according to one reviewer (Dotzauer 2007: 22). In some cases reviewers would abstain from evaluating a work, as they cannot find relevant criteria for an evaluation due to the big cultural differences (Müller 2007: 16).

Hence, the assumed peculiarities of Japanese culture are often mentioned as the reason for difficulties of understanding Japanese literature. It is the culture-not a deliberate act of the author-that produces an obscure text; it is the context and not the text that is incomprehensible for the authors of these review articles. However, critics still prefer these works to texts that are presumably too easy to understand, because in their opinion, typical Japanese characteristics are missing.

\section{Superficiality}

The notion of superficiality or shallowness is the antipode to obscurity in this context. While obscurity is seen as rather positive, because it is attributed to high complexity and cultural differences, works that are easy to understand are thought to lack complexity and depth and are therefore seen as superficial. This critique is frequently directed at the popular authors Murakami and Yoshimoto (Kunisch 2003: 16; Scholz 2003: 14; KC 2005: 113). 
It follows that literary works, which transcend the immediate political, social, and cultural surroundings of their authors, are often deprecated for being shallow. Authors of such works are criticised for making too many concessions to a 'homogeneous readership' (homogene Leserschaft) of a 'global literature' (weltumspannende Literatur), as one reviewer described it (Form 2003: 10). 'Global literature' reiterates the accusation of detachment of the Japanese cultural context and the 'homogeneous readership' seems to be the cause of the supposed superficiality. However, as the subjects here are works that became worldwide best sellers, 'homogeneous' readership simply seems to mean 'large' readership, as uniformity among so many readers cannot be assumed. In other words, literature that is removed from the context of the national culture that produced it can appeal to a big audience beyond national borders but is often lacking in quality.

Another reviewer puts the blame for the emptiness of Murakami's works on the emptiness of Japanese society and the limitless wealth and lack of passion of the Japanese people. It is the shallowness of contemporary Japanese culture that results in the shallowness of its literature for this reviewer (Federmair 2003: 37). The mentioned review also traces the superficiality back to the issue of globalisation and the accusation of its negative influence on Japanese society. Thus, the reviewer describes superficiality not only as a characteristic of Murakami's works but of the globalised era in which they were produced.

\section{Metropolis and Loneliness}

Life in a metropolis, mostly Tōkyō, and all the problems it entails, is often depicted as an important theme in contemporary Japanese literature. For Murakami's works the term 'metropolis' is used as generic term for the loneliness of its inhabitants and the shallowness of human relations (Stüttgen 2003: 18); as a setting, the big city is important for the mood of mystery and suspense (Huber-Lang 2005: 21; Baron 2005b: 23). In the works of Yoshimoto, the big city is also depicted as an important theme (Ertl 2004:9), as well as influencing her writing style (Weissmüller 2005: 14; KC 2005: 113).

The review "Im Land der einsamen Großstadtwölfe" (In the Land of Lone Wolves of the Big Cities) deals with four works of four different authors: Kanehara Hitomi's 金原ひとみ (b. 1983) Tokyo love (Hebi ni piasu 蛇にピアス); Murakami's Blinde Weide, schlafende Frau: Erzählungen; ${ }^{7}$ Murakami Ryū's 村上龍 (b. 1952) In der Misosuppe (In za miso sūpu イン ザミソスープ); and Tsuji Hitonari's 辻仁成 (b. 1959) Warten auf die Sonne (Taiyō machi 太陽待ち) under the

7 This collection of stories has been compiled for the German language book market. The title refers to one of the stories in the collection, "Mekura yanagi to nemuru onna” くくやなぎと眠る女 (Blind Willow, Sleeping Woman) first published in December 1983 in the magazine Bungakukai. 
topic of the metropolis. The reviewer argues that life in a big city like Tōkyō is an important subject matter not only for the mentioned works but also for Japanese literature in general. This kind of life is normally used as a metaphor for loneliness. For example, in a review of Kawakami's Der Himmel ist blau, die Erde ist weiß, the loneliness of the life in a big city is described as an important motif for the actions of the female protagonist (Neidhart 2008: 55).

Hence, many articles highlighted the feeling of being isolated or alone that comes with the life in a metropolis, which, in the view of the respective reviewers, frequently is conveyed by Japanese literary works. Above that, in a review of Kirino's Die Umarmung des Todes another factor comes into play. The reviewer connects the corrosion of Japanese society by globalisation with the theme of loneliness and ultimately with madness and violence (Gohlis 2003: 50). These associations are frequently used in the review articles.

\section{Violence}

On the one hand, violence is described as an important part of Japanese aesthetics. For one reviewer there is a typical Japanese relation between innocence and cruelty (Winkels 2003: 42), and another one sees a characteristic connection of lust and death in Japanese art (Sperl 2003: 7). On the other hand, violence is interpreted as a consequence of problems within Japanese society. Many reviews adopt this view and attempt to explain these problems with the help of the literary works they are concerned with:

In Made in Japan (Meido in Japan メイドインジャパン) by Kuroda Akira 黒 田晶 (b. 1977), the violence of the teenagers is a symptom of the crisis of Japanese society according to one reviewer (Mensing 2005: vi). In the same article, Japan is described as a devastated nation with no self-esteem after the burst of the bubble economy at the beginning of the 1990s. This allegedly produced a violent-prone lost generation. The naturalistic depiction of the socio-economic background of the violence in the novel is considered to be the reason for its quality. Furthermore, the novel is twice compared to American Psycho (Wedler 2005: 18; Mensing 2005: vi). It is, however, rated higher than its US-American counterpart by its reviewers on the grounds that it is based on real social and economic problems in Japan.

It is teenagers in Made in Japan and middle-class women in Die Umarmung des Todes by Kirino who are driven to violence by society according to most reviewers. Die Umarmung des Todes is characterized as a case study about how the economic crisis affects the weakest of society (Neidhart 2003: 91; Sperl 2003: 7). It is described as a dark novel about the cruelty of Japanese society (Sperl 2003: 28), providing precious insight into the values of this society (Schoettli 2003: 35). Again it is the background of these perceived problems of Japanese society that helps the 
reviewers to explain the violence in this novel and adds value to it. The same argument is employed by a critic for the Der Hai von Shinjuku (Shinjuku zame 新宿鮫) series $^{8}$ written by Ōsawa (Staude 2008b: 38).

By contrast, Tsutsui's Mein Blut ist das Blut eines anderen (Ore no chi wa tanin no chi おれの血は他人の血) causes slight irritation for one reviewer (HijiyaKirschnereit 2007: 58). The reviewer cannot see the point of the depicted violence, because it does not educate the readers about Japanese society. This is how violence is treated in the reviews: it is accepted as a part of Japanese aesthetics, but it is expected to provide a better understanding of Japan. If it has no obvious relation to real social problems in Japan, it is a reason to deprecate a literary work as lowbrow and lacking depth.

\section{Feminism}

The depiction of the problems for women in Japanese society is an important issue for reviewers of Japanese literature. Women are understood to have a low status in Japanese society. One critic summarises the situation in a review about Die Umarmung des Todes by Kirino:

Bis heute findet eine Mehrheit der Japanerinnen nur Teilzeitjobs. Und dort werden sie drangsaliert und nur ausgenutzt, als ganzes Geschlecht an den Rand einer Gesellschaft gedrängt, deren Mitte zusehends verrottet (Neidhart 2003: 91).

Kirino is characterised as an author who depicts female characters standing in stark contrast to the official Japanese concept of women in Die Umarmung des Todes (Sperl 2003: 7) and who creates authentic female characters (Schoettli 2003: 35). The violence in this novel is said to be caused by the humiliating living conditions of Japanese women (Sperl 2003: 28). Furthermore, the author is also praised for breaking taboos with the novel and thereby risking to cause the resentment of Japanese literary critics (Neidhart 2003: 91; Händler 2004: 6).

Die Geschichte einer gewissen Frau by Uno is also described as dealing with the status and problems of Japanese women. The conflict for women in this work comes from the changes during the period of modernisation. The novel is understood to be slightly subversive, because the female protagonist does not choose a life appropriate for her gender (Lütkehaus 2004a: 48). Another perspective on gender relations is seen in Kurahashi Yumiko’s 倉橋由美子 Die Reise nach Amanon (Amanon-koku

8 Two novels have been published in German: Der Hai von Shinjuku: Sodom und Gomorra (Shinjuku zame 新宿鮫) and Der Hai von Shinjuku: Rache auf Chinesisch (Shinjuku zame II: Dokuzaru 新宿鮫 II: 毒猿)

9 'Until today, the majority of Japanese women can only find part time jobs. And in these they are harassed and only exploited; the whole female gender is being pushed to the fringes of a society whose centre deteriorates increasingly' (translation by author). 
okanki アマノン国往還記). Her playful handling of gender roles demonstrates the irrationality of stereotypes according to one article (Gnam 2006b: 34).

Feminism is an important issue for reviewers when the reviewed works are written by women. Often very dire living conditions for women are assumed for Japan and are described in the articles. Many critics had a strong reaction to the connection of the description of women's lives and the violent story in Die Umarmung des Todes.

\section{Harmony and the Calm Stream of Language}

It is striking how often the mood in the reviewed works is described as harmonious and the style is compared to a calm stream. The tone of Murakami's writing is described as flowing (Teuffel 2008: 28). The styles of Uno (Lütkehaus 2004a: 48) and Ogawa (Gnam 2004b: 38) are similarly presented and many reviewers portray Kawakami's style as smoothly flowing (Messmer 2008: xi) or with comparable attributes like quietness (Neidhart 2008: 55); described as very slow (Krekeler 2008: 5 ); a quietly whispering language which provides contemplative pleasure with simple sentences (Winkels 2008: 53). Yoshimura Akira's 吉村昭 (1927-2006) Unauslöschlich (Karishakuhō 仮釈放), in comparison, is described as structurally composed to give the reader the impression of a slow cruise on a river (Fokke 2007: 14).

Therefore, reviewers sometimes find a harmonious flow in the language and sometimes also in the structural composition of a literary work. No review article expresses surprise about the language of the considered Japanese literary works, the progression of the stories, or the structural composition of the works that are frequently described as smoothly or quietly flowing. This 'smoothness' measures up to the reviewers' expectations and contrasts the theme of violence but also corresponds to the issues of esotericism and transience raised in many reviews.

\section{Esotericism and Transience}

The term 'esoteric' is used for the works of very different authors. The difficulties in understanding the works of Ōe are sometimes explained by an alleged Japanese esotericism and Asian spirituality (Federmair 2004b: 4; Cavelty 2005: 61). The characters in Ogawa's Museum der Stille (Chinmoku-hakubutsukan 沈黙博物館) are said to have mysterious connections to nature and invisible forces (Echo 2006: 83) and Murakami is described as creating a mysteriously spiritual mood (Albath 2006: 14). According to many reviewers, esotericism is particularly characteristic of Yoshimoto and part of her formula of success (KC 2005: 113; JDL 2007: 26). 
Yoshimoto is also said to create a pathos of transience (Vergänglichkeitspathos) in her works (Gnam 2004d: 40).

The notion of transience derives, similar to that of esotericism, from a vaguely assumed Asian spirituality. It is described as an important motif in the works of Tanizaki (Gnam 2003: 36), whose works are also said to correspond with ukiyo-e 浮 世絵 (Lütkehaus 2003b: 15), Japanese woodblock prints of the floating world (floating meaning transient), hence placing the theme of transience in a Japanese tradition. Likewise, it is identified as a motif of the works of Higuchi (KOS 2008: $34)$.

The term 'esotericism' is especially used to criticise popular contemporary authors, whereas the motif of transience is described as part of Japanese tradition. In the sense that both are associated with the notion of 'Asian spirituality', they are also related to the realm of fantasy, which is another important aspect in the review articles.

\section{Reality and Fantasy}

Switching between reality and fantasy within one story is depicted as characteristic of Japanese literature. One reviewer attributes the origins of this aspect in Yoshimoto's stories to Shintōism (Ertl 2004: 9). The phenomenon is also ascribed to works by Akutagawa (Gnam 2004a: 34) and Ogawa (Federmair 2005: 37, 2006b: 28). It is, however, mostly associated with Murakami and referred to as an inherent part of the mood in his works (Kospach 2003a: 7; Körte 2003: 8), as a crucial element of the composition of his stories (Baron 2005b: 23; Wiegandt 2008: 14), and as a characteristic aspect of his style (Löhndorf 2006: 27).

This literary device of switching between reality and fantasy is explicitly connected to the influence of Latin American magical realism in one review article about Murakami and Ikezawa (Hijiya-Kirschnereit 2003a: 34). This indication of influence contrasts the widely spread opinion that having elements of reality and fantasy in the same text was a typical quality of Japanese literature. It still emerges, however, as a common trait of Japanese literature in most of the review articles.

\section{Genres}

Reviewers very rarely write about Japanese literature and its history in general. Only when they want to emphasise the importance of an author do they explain the status of this author within the history of Japanese literature. However, sometimes certain genres are mentioned. One typical Japanese genre which is frequently described by reviewers is the so-called shishōsetsu 私小説. 
The generic term 'shishōsetsu' is explained in a review about Ōe's Tagame. The reviewer describes the genre as consisting of autobiographic essays, starting with a personal experience and involving intense self-scrutiny by the author, which comes close to exhibitionism (Cavelty 2005: 61). Such novels are seen as outmoded. Therefore the term is used as a criticism of Ōe's works, whose style is described as annoyingly self-centred by another critic (Hijiya-Kirschnereit 2008b: 11).

Mystery stories from Japan, in contrast, are widely praised. Many reviewers like that these stories go beyond the typical confines of the genre (Hijiya-Kirschnereit 2003c: 34; Schoettli 2003: 35; Wörtche 2008: 16). Works of Edogawa Ranpo 江戸 川乱歩 (1894-1965) are especially lauded and his significance for the development of the genre in Japan is stressed (Gnam 2006a: 38; Mensing 2006: vi). Several contemporary mystery novels have been released by Cass Publishing with some success. Higashino Keigo’s 東野圭吾 (b. 1958) Mord am See (Reikusaido レイク サイド) is praised for its connection to an authentic background and suspense (Hijiya-Kirschnereit 2003c: 34), as are volume one and two of the novel Der Hai von Shinjuku with the addition of an action-packed story (Staude 2008b: 38; Wörtche 2008: 16). The above-mentioned series Die Umarmung des Todes is also one of the successful works that are praised particularly for their authentic socio-economic background story. The realistic insight into Japanese society is stressed as a point that makes a mystery story praiseworthy. Works that have mystery elements but do not offer such insight are much less well received. Examples are Mizukami Tsutomu's 水上勉 (1919-2004) Im Tempel der Wildgänse (Gan no tera 雁の寺) and Tsutsui's Mein Blut ist das Blut eines anderen.

\section{Mistakes}

My analysis of review articles of Japanese literature has shown that reviewers are prone to making mistakes. The attention here shall not be directed to typing errors but to incorrect information and/or misconceptions that are often part of these review articles. Sometimes book titles are confused. One review cites Naokos Lächeln (Noruwei no moriノルウェイの森), translated from Japanese into German, instead of Gefährliche Geliebte, translated from English into German, as the novel by Murakami that caused the argument in the literary TV show Das Literarische Quartett (Kastura 2003: 4). In another article the reviewer refers to a book by Murakami allegedly titled Beben von Kobe, which is in fact called Nach dem Beben (Kaufer 2004: 7).

Other mistakes are that the name 'Edogawa Ranpo' is said to be an acrostic (Lütkehaus 2006: 28), ${ }^{10}$ that Mishima is mistaken for a winner of the Nobel Prize for

10 This is incorrect. Rather, 'Edogawa Ranpo' is a phonetic approximation of the name 'Edgar Allan Poe', using the Japanese readings of Chinese Characters (江 e 户 do 川 gawa 亂 ran 步 po). 
literature (Müller 2008: 16), and that one reviewer explains that the name 'Kafka' is written 'Kafuka' in transliteration because 'a Japanese cannot pronounce the word Kafka' (Müller 2004: 16). ${ }^{11}$ The most frequent mistake however is the misspelling of names. This did not only occur once as a typing error but every time when the name was mentioned in the same article: 'Yakoi' instead of 'Yayoi' and 'Natsuro' instead of 'Natsuo' (Fischer 2003: 28); 'Takeshi' instead of 'Takashi' (Ballhausen 2003:8); 'Kanahara' instead of 'Kanehara' (ABN 2006: 26); 'Saturo' instead of 'Satoru' (Neidhart 2008: 55).

\section{Conclusion}

Japanese literature is in a stronger position in the German-language book market than it was in the 1990s. This is partly due to the impact of best-selling authors like Murakami, but it is also partly due to the support of Japanese institutions as well as smaller initiatives by literature conveyors in German-speaking countries. The controversy around Murakami's Gefährliche Geliebte helped to strengthen the position of Japanese translators. It is agreed that the controversy arose at least to some extent from the fact that the German version was translated from the English version. It is now common to translate from the original Japanese into German.

Japanese literature is most frequently discussed in the Swiss and German newspapers Neue Zürcher Zeitung, Frankfurter Allgemeine Zeitung, Zeit, Welt, Süddeutsche Zeitung, and taz. The reviewers are mostly experts of literature in general but not of Japanese literature. Of the six reviewers who wrote more than five review articles in the period under investigation only one (Hijiya-Kirschnereit) is a distinguished expert of Japanese studies. As Hubert Spiegel relates, editors fear that Japanese studies experts would be biased (Spiegel 2001: 94). It is assumed/suspected that they would be keen to dissolve stereotypes and advocate an 'authentic' picture of Japanese society or literature. Therefore, they might overstate the value of works that depict an accurate socio-economic background story or constitute a representative example of Japanese literature and dismiss works that offer no such insights. This reluctance to employ Japanese studies experts, however, leads to frequent mistakes concerning facts about Japan and Japanese literature and culture in the review articles.

The image of Japanese literature, created by the reviewers, is that of a literature that deals, thematically, with the collision of traditional Japanese culture and West-

11 To render the name 'Kafka' in Japanese, a syllabary has to be used, in this case the katakana, which only allows the combination of syllabograms plus the coda ' $n$ ' (ン). There is no ' $f$ ' available in the Japanese writing system, only a syllabogram for 'fu', which has to be used to render the name 'Kafka' in Japanese writing. This writing convention, however, says nothing about the ability of Japanese citizens to pronounce foreign names. 
ern culture; that is sometimes difficult to understand for Western readers, if the themes and motifs are too foreign, but that also is superficial if the themes and motifs are too far detached from the Japanese context; that addresses the manifold problems of a high-tech society, the loneliness in the metropolises, and the oppression of women; that has a tendency toward esotericism, and in which fantasy elements are common; and, finally, that has many interesting and exciting aspects to offer in the mystery genre.

These various themes, which the reviewers in German print media attribute to Japanese literature as main themes, attest to a broadened level of expectation among most of the reviewers. Uncritically adopted stereotypes of Japanese society and Japanese literature have become rare in reviews of translated Japanese literature. The use of stereotypes, however, has not disappeared completely but has become subtler. Experienced readers of Japanese literature have expanded their expectations. Previously these expectations consisted mainly of 'subtle aesthetics', now they also include the 'aesthetics of the broken' ('Ästhetik des Kaputten', Hijiya-Kirschnereit 2003c: 34). These 'aesthetics of the broken', which still shocked reviewers in the early 1990s (Hijiya-Kirschnereit 1996: 706-7), are now expected by most reviewers: they are perceived to attest to problems of Japanese society. The crucial point, however, is that in the opinion of many reviewers something true and authentic should be conveyed about Japanese society in the work of a Japanese author. It seems that reviewers, as the knowledge about Japanese society has increased significantly among them, confidently focus on elements of literary texts they perceive to be confirming their knowledge about Japanese society, culture, economics, or politics. If reviewers feel that a Japanese work of literature does not convey the reality of life in Japanese society, it is described as lacking quality. This is illustrated by the reviews of Tsutsui's Mein Blut ist das Blut eines anderen where the depicted violence allegedly does not attest to the reality of Japanese society or by the reviews of the works of Murakami that are supposedly intended for a global audience and therefore perceived to be lacking a quality that could be called 'Japaneseness', as well as the reviews that describe the works of Ōe as either too obscure or too selfcentred and therefore far detached from real (Japanese) life.

The conclusion therefore must be that while on the one hand the expectations of Japanese literature have broadened and reviewers are not as easily shocked as they were in the past, on the other hand even experienced readers still expect Japanese literature to paint a truthful picture of the state and the problems of Japanese society. Literature can be a source of information about a foreign culture, but it cannot be the main duty of authors to act as cultural mediators. Futhermore, the authenticity of information cannot count as a viable criterion for the evaluation of a work of (literary) art-unfortunately it is, however, still used by many reviewers. 


\section{REFERENCES}

\section{Primary Sources: Review Articles}

ABN. “"Chick-Lit, japanisch”" In NZZ, 30 December 2006, p. 26

ABN. "Belletristik: Junge Frau und alter Mann.” In NZZ, 23 February 2008, p. 27

AGI. “Lesart.” In Stuttgarter Zeitung, Sonntag Aktuell supplement, 28 August 2005, p. 17

Albath, Maike. "Der einbeinige Geist des Surfers. Abstauber des Surrealismus: Haruki Murakamis Erzählungen.” In SZ 22 December 2006, p. 14

Amanshauser, Martin. "Die Eitelkeit des Erstentdeckers: Martin Amanshauser über seinen Lieblingsautor Haruki Murakami und dessen neuen Roman 'Sputnik Sweetheart." In Standard, Album supplement, 18 January 2003, p. 6

Amanshauser, Martin. "Bekenntnisse über japanische Un-Japaner: Eine gerade verfilmte Erzählung von und eine Biographie über Haruki Murakami.” In Standard, 11 June 2005, p. 5 (Standard Album)

Angerer, Peter. “Tiroler Trachtenmode.” In Tiroler Tageszeitung, Magazin supplement, 8 February 2003a, p. 6

Angerer, Peter. "Glück und Pech: Mit 'Der atemlose Stern' liegt die komplette Trilogie 'Grüner Baum in Flammen' von Kenzaburô Ôe in deutscher Übersetzung vor.” In Tiroler Tageszeitung, Magazin supplement, 29 November 2003b, p. 6

Angerer, Peter. “Absoluter Minimalismus.” In Tiroler Tageszeitung, Magazin, 13 August 2005, p. 6

AWI. "Literatur: Ein seltsames Liebesverhältnis.” In Frankfurter Rundschau, 29 July 2008, p. 32

Ballhausen, Thomas. "Liebe zwischen Ruinen: Banana Yoshimotos mythologisch verbrämter Roman 'Sly." In Wiener Zeitung, extra supplement, 4 April 2003, p. 8

Baron, Ulrich. "Die Nacht der Seele: Kenzaburō Ōe erzählt sehr mystisch von japanischen Ökos." In Zeit, Literatur supplement, 9 October 2003, p. 46

Baron, Ulrich. “Abschied von der Zeit: Mit 'Tagame' hat Kenzaburo Oe eine sehr subtiles, persönliches Buch geschrieben.” In Zeit, Literatur supplement, 8 December 2005a, p. 18

Baron, Ulrich. "Wie wir uns verpassen: Haruki Murakami Der große Erzähler bleibt seinen mysteriösen Sujets treu." In Rheinischer Merkur, 22 December 2005b, p. 23

Baron, Ulrich. "Leichthändiger Zeichner: Erzählungen, Haruki Murakamis schattenhafte Geschichten aus mehreren Jahrzehnten ziehen in Bann." In Rheinischer Merkur, 21 September 2006a, p. 21

Baron, Ulrich. "Die Indianer sind gar nicht da." In Welt, Die literarische Welt supplement, 7 October 2006b, p. 4

Baron, Ulrich. "Der nützliche Lötkolben. Miteinander verdrahtet: Erzählungen von Haruki Murakami." In SZ, 23 March 2007, p. 16

Baron, Ulrich. "Krakenleib, zartrosa: Hiromi Kawakami erzählt von einer Liebe, die beinahe so kompliziert ist wie die japanische Küche.” In SZ, Literatur supplement, 11 March 2008, p. 5

Bartmann, Christoph. "Zwischen 23:56 und 6:52 Uhr: Eine Prostituierte ist von ihrem Freier misshandelt worden, und nun sinnen ihre Zuhälter auf Rache. In 'Afterdark' taucht Haruki Murakami tief ins Vorfabrizierte ein.” In Presse, Spectrum supplement, 25 February 2006, p. xiii

Berg, Sibylle. "So leben wir also weiter. Haruki Murakamis neuer Roman." In Welt, Die literarische Welt supplement, 20 March 2004, p. 2 
Berg, Sibylle. "Die ewig schöne Murakami-Melodie: Er hält kurz inne, im Neonlicht, das diesmal etwas trist leuchtet - aber die Reise mit ihm geht weiter, weil seine Sätze süchtig machen.” In Zeit, 24 November 2005, p. 60

Böttiger, Helmut. "Zirkeltraining mit Johnny Walker. Haruki Murakami sucht 'Kafka am Strand' und findet noch ganz andere Sachen.” In Zeit, Literatur supplement, 1 March 2004, p. 26

Breitenstein, Andreas. "Noch Leben drin: Eine kulinarische Liebesgeschichte von Hiromi Kawakami." In NZZ, 1 March 2008, p. 27

Cavelty, Gieri. "Vergesst die Toten, vergesst auch die Lebenden: In seinem Roman 'Tagame. Berlin - Tokyo' verarbeitet der japanische Nobelpreisträger Kenzaburo Oe den Selbstmord seines Freundes Juzo Itami." In Tagesanzeiger, 16 September 2005, p. 61

CJW. “Zarte Liebesbande.” In Tiroler Tageszeitung, Magazin supplement, 10 December 2005, p. 6

Cornu, Charles. "Romane und Erzählungen: Dialog mit einem Toten.” In Bund Der kleine Bund, 5 November 2005, p. 7

Dell, Matthias. "Liebe auf den ersten Biss: Speiseplan. Der richtige Geschmack ist bei Hiromi Kawakami eine Sache des Gefühls." In Freitag, 14 March 2008, pp. 15 and 24

Detje, Robin. "Das bittersüße Mixgetränk. Kult ist Soundtrack und Tapete: Haruki Murakamis Roman 'Afterdark." In SZ, 15 December 15, 2005, p. 16

Dotzauer, Gregor. "Das Pendel, das die Welt bewegt: In 'Kafka am Strand' wagt Haruki Murakami einen Parforceritt durch die westliche Mythologie.” In Tagesspiegel, 24 March 2004, p. 27

Dotzauer, Gregor. "Tasse und Schwert: Zum 100. Geburtstag von Yasushi Inoue erscheint 'Der Tod des Teemeisters."” In Tagesspiegel, 5 May 2007, p. 22

Droschke, Martin. "Gefährliche Grapefruits. Japan: Aki Shimazaki beschreibt den Abwurf der Atombombe als Befreiung, Yoko Ogawa nimmt sich der ökologischen Katastrophe an.” In Falter, Falter spezial supplement, 21 March 2003, p. 11

DW. "Kurz und Knapp. Sayonara, meine Bücher." In Welt, Die literarische Welt supplement, 6 December 2008, p. 3

Ebel, Martin. "Literatur: Kenzaburo Oe über Terror und Literatur." In Tagesanzeiger, 20 December 2008, p. 46

Echo. "Erschüttert: Aus der Bahn." 1 February 2004, p. 79

Echo. "Märchenhaft: Was von Toten bleibt." 1 March 2006, p. 83

Ellsäßer, Rebecca. "Kurz und knap: Hard-boiled. Hard Luck. Zwei Erzählungen. Von Banana Yoshimoto." In Welt, Die literarische Welt supplement, 24 April 2004, p. 4

Engels, Josef. "Murakami spielt sich warm." In Welt, Die literarische Welt supplement, 4 February 2006, p. 4

Erler, Isabelle. "Am Ende ein Lachen. Beruhigend absurd: Der hinreißende Roman des japanischen Bestsellerautors Haruki Murakami.” In Kinder, Kinder! Neue Jugendliteratur, 24 November 2004, p. 6

Ertl, Sabine. "Wütender Wurm. Haruki Murakamis Erzählungsband 'Nach dem Beben.”' In Wiener Zeitung, extra supplement, 7 November 2003, p. 11

Ertl, Sabine. "Wie im tiefsten Traum. Haruki Murakami dringt tief ins Unbewusste." In Wiener Zeitung, 16 July 2004, p. 9

Federmair, Leopold. "Literatur zum Wohlfühlen. Haruki Murakamis Erzählungen 'Nach dem Beben." In NZZ, 13 November 2003, p. 37

Federmair, Leopold. "Vater töten spielen. Die wilde Erzähllogik des Haruki Murakami." In Standard, Album supplement, 17 April 2004a, p. 5

Federmair, Leopold. "Die Belange der Seele: Warum Kenzaburo Oe immer noch gute Bücher schreibt.” In Standard, Album supplement, 22 May 2004b, p. 4 
Federmair, Leopold. "Der Einsatz der Leere: Yoko Ogawas Roman 'Liebe am Papierrand.'” In NZZ, 17 February 2005, p. 37

Federmair, Leopold. "Warum hat sich Juzô Itami umgebracht? Kritik und Selbstkritik in Kenzaburō Ōes neuem Roman.” In Standard, Album supplement, 14 January 2006a, p. 5

Federmair, Leopold. "Elaborierte Phantastik: Yoko Ogawas Roman 'Das Museum der Stille.'” In NZZ, 18 April 2006b, p. 28

Federmair, Leopold. "Der Jäger als Menschenfreund. Einsamkeit und Einfühlung - vor hundert Jahren wurde der japanische Schriftsteller Yasushi Inoue geboren." In NZZ, 5 May 2007, p. 28

Fischer, Andrea. "Wohlstand schützt vor Bosheit nicht." In Tagesspiegel, 1 June 2003, p. 28

Fokke, Joel. "Zwang zur Harmonie. Wiedereingliederung - Akira Yoshimuras Roman 'Unauslöschlich."” In Freitag, 5 January 2007, p. 14

Form, Andreas. "Japanerinnen auf Reisen. Haruki Murakami: 'Sputnik Sweetheart."' In Neues Deutschland, 24 January 2003, p. 10

Frisè, Maria. "Schneelandsleute. Verirrt im Labyrinth der Erinnerung: Yoko Ogawas Roman." In FAZ, 24 January 2005, p. 34

Furche. "Tod als Gast(geber). Am 6. Mai wäre er 100 Jahre alt geworden: Der japanische Autor Yasushi Inoue. Sylvia M. Patsch las seinen Roman 'Der Tod des Teemeisters,"” 3 May 2007, p. 18

Gauss, Karl-Markus. “Aus dem postmodernen Warenhaus. 'Kafka am Strand': Haruki Murakami gibt Rätsel auf." In NZZ, 5 June 2004, p. 48

Geese, Lilian-Astrid. "Für starke Nerven. Tsustui Yasutaka: Thriller aus Japan.” In Neues Deutschland, Literaturbeilage supplement, 25 November 2006, p. 6

Gnam, Steffen. "Im Reich der Hintersinne. Dämonische Kunst: Ein filigranes Frühwerk von Junichiro Tanizaki." In FAZ, 3 November 2003, p. 36

Gnam, Steffen “Steppenwolf in Tokio. Das Spätwerk des 'Rashomon'-Autors Ryûnosuke Akutagawa." In FAZ, 15 January 2004a, p. 34

Gnam, Steffen. "Warum regnet es auf mich? Schwarze Romantik: Drei Erzählungen von Yôko Ogawa." In $F A Z, 2$ March 2004b, p. 38

Gnam, Steffen. "Freudenmädchen Hand in Hand. Tokios Tanz auf dem Vulkan: Nagai Kafûs Tagebuch beleuchtet 1937." In FAZ, 12 March 2004c, p. 36

Gnam, Steffen. "Pop und Haikus: Blasse Schatten des Lebens: Banana Yoshimotos Erzählungen." In FAZ, 14 May 2004d, p. 40

Gnam, Steffen. "Trunken von Sake und Rimbaud. Gedächtniskamera: Kenzaburô Ôes virtuoser Künstlerroman.” In FAZ, 6 September 2005, p. 36

Gnam, Steffen. "Schönheit und Schauer. Meister der Illusionen: Japans Krimiklassiker Edogawa Rampo.” In FAZ, 16 February 2006a, p. 38

Gnam, Steffen. "Im Irrgarten des Systems. Amazonenstaat: Yumiko Kurahashis allegorische Japan-Satire.” In FAZ, 5 September 2006b, p. 34

Gnam, Steffen. "Rote Sonne. Falsch belichtet: Hitonari Tsuji erzählt von einem alten Regisseur." In FAZ, 16 March 2007a, p. 34

Gnam, Steffen. "Die Aussichten - unbeständig. Higuchi Ichiyôs zartbittere Chronik Japans.” In FAZ, 27 September 2007b, p. 34

Gnam, Steffen. "Verrannt in die Anderswelt. Laufend der Leere entgegen: Haruki Murakami philosophiert über die Analogie von Laufen und Schreiben - und deckt damit sein poetologisches Verfahren auf." In FAZ, 1 August 2008a, p. 34

Gnam, Steffen. "Tod im Tempel. Ein Schauermärchen aus Japans Klosterwelt.” In FAZ, 17 November 2008b, p. 34 
Gohlis, Tobisa. “Die scharfen Messer der japanischen Frauen. Kriminalroman.” In Zeit, 20 November 2003, p. 50

Görner, Rüdiger. "“Vergesst Tote und Lebende.' Voll subtiler Ironie: In seinem neuen Roman, 'Tagame. Berlin-Tokyo,' plaudert Kenzaburo Ōe auch sein 'erzähltechnisches Betriebsgeheimnis' aus." In Presse, Spectrum supplement, 4 February 2006, p. ix

Gutschke, Irmtraud. "Fluss des Lebens. Banana Yoshimoto war in Ägypten.” In Neues Deutschland, 24 January 2003, p. 10

Händler, Siggi. "Eine Leiche auf Reis: Japans großer Schnitt.” In Welt, Die literarische Welt supplement, 24 January 2004, p. 6

Heidkamp, Konrad. "Belletristik. Büchertisch.” In Zeit, 1 September 2005, p. 52

Hijiya-Kirschnereit, Irmela. "Teigwaren der Globalisierung. Mythologie in der Südsee: Ikezawa Natsuki erzählt unter Palmen.” In FAZ, 10 March 2003a, p. 34

Hijiya-Kirschnereit, Irmela. "Im Stechschritt in die Freiheit. Haftpflicht: Akira Yoshimuras Roman eines Bewährungsversuchs.” In FAZ, 29 April 2003b, p. 35

Hijiya-Kirschnereit, Irmela. "Gehört der Gatte zum Biomüll? Außenseiter in der Überflussgesellschaft: Zwei Krimis aus Japan.” In FAZ, 13 October 2003c, p. 34

Hijiya-Kirschnereit, Irmela. "Archiv der abgelegten Erinnerung. Lebensmüde am Beckenrand: Yôko Ogawas morbide Erzählung.” In FAZ, 8 April 2004a, p. 40

Hijiya-Kirschnereit, Irmela. "Wenn der Teekessel singt. Ein Klassiker: Yasunari Kawabatas 'Schneeland' neu übersetzt." In FAZ, 18 September 2004b, p. 38

Hijiya-Kirschnereit, Irmela. "Stundenweise Horror. Es riecht nach Geheimnis: Haruki Murakami als Voyeur." In FAZ, 26 April 2006, p. 40

Hijiya-Kirschnereit, Irmela. "Thriller mit Hang zur Raserei. Chance versiebt: Yasutaka Tsutsui erscheint erstmals auf Deutsch." In FAZ, 9 March 2007, p. 38

Hijiya-Kirschnereit, Irmela. "Lotuswurzelbehandlung. Die Liebe folgt der Jahreszeit: Hiromi Kawakami erzählt von der Einsamkeit japanischer Großstadtmenschen und dem Glück eines ungleichen Paares." In FAZ, 26 March 2008a, p. 34

Hijiya-Kirschnereit, Irmela. "Ich, ich, immer nur ich. Ein Tag im Leben des Kogito: Bei Kenzaburô Ôe begegnen wir alten Bekannten.” In $F A Z, 15$ October 2008b, p. 11

Höge, Helmut. 'Die Äußere Mongolei als japanische Innerei: 'Mister Aufziehvogel' - Haruki Murakami erinnert sich stellvertretend für seine Landsleute an die Hölle und das verlorene Paradies in der japanisch besetzten Mandschurei." In Frankfurter Rundschau, 13 December 2003, p. 18

Huber-Lang, Wolfgang. "Grenzüberschreitung im Großstadt-Dunkel. Buch: ‘Afterdark' - Haruki Murakamis neuer Roman in Deutsch erschienen.” In OÖ Nachrichten, 12 December 2005, p. 21

JAL. "Immer und Ewig. Lob des Schattens." In Wochenzeitung, September 22, 2005, p. 22

JDL. "Hinweise auf Bücher. Ewig treue Herzen." In NZZ, 2 July 2007, p. 26

Kastura, Thomas. "Verschüttete Nächstenliebe: Erzählungen, Haruki Murakami verarbeitet subtil das dramatische Erdbeben von Kobe." In Rheinischer Merkur, extra supplement, 4 December 2003, p. 4

Kaufer, Stefan. "Riesenfrosch gegen Erdbebenwurm: In sechs Erzählungen beschäftigt sich der japanische Autor Haruki Murakami mit dem Erdbeben von Kobe.” In Salzburger Nachrichten, Lebensart supplement, 28 February 2004, p. vii

KC. "David Hamilton: Erzählungen.” In Profil, 13 May 2005, p. 113

Klingenmaier, Thomas. "Der aktuelle Krimi. Provinzler, Rechtsradikale und andere Durchmogler." In Stuttgarter Zeitung, 1 February 2008a, p. 40

Klingenmaier, Thomas. “Krimi. Tokios Rotlichthai.” In taz, 31 March 2008b, p. 50 
Kluge, Friedmann. "Jesuiten in Japan. Kaga Otohiko führt ins 17. Jahrhundert.” In Neues Deutschland, 28 December 2006, p. 12

Klüger, Ruth. "Die späte Liebe. Ruth Klüger hat Bücher von Frauen gelesen.” In Welt, Die literarische Welt supplement, 27 December 2008, p. 7

Körte, Peter. "Der Schrecken ist ein leiser Schatten. Kontinentalverschiebungen der Seele: Neue Erzählungen von Haruki Murakami." In FAZ, 7 October 2003, p. 8

KOS. "Kritik in Kürze. Poetisches Blatt." In FAZ, 5 December 2008, p. 34

Kospach, Julia. "Monumentale Leidenschaft: Haruki Murakami, gefeierter Schriftsteller Japans, eröffnet seinen Helden im Roman 'Sputnik Sweetheart' zauberhafte Auswege aus ihren Lebens- und Liebeskrisen.” In Bund Der kleine Bund, 1 March 2003a, p. 7

Kospach, Julia. "Die kluge Krähe Kafka. Haruki Murakamis neues Buch 'Kafka am Strand': Ein Entwicklungsroman voller Grenzgänge zwischen Traum und Wirklichkeit.” In Bund Der kleine Bund, 29 May 2003b, p. 9

Kospach, Julia. "Schutt und Asche: Erzählungen.” In Profil, 1 December 2003c, p. 123

Kospach, Julia. "Fischregen: Roman.” In Profil, 24 May 2004, p. 129

Kraßnitzer, Michael. "Gefährlicher Roman: Haruki Murakamis 'Sputnik Sweetheart' im Kasino des Burgtheaters." In Furche, 30 March 2003, p. 15

Krekeler, Elmar. "Frauen, die zu viel Sake trinken. Hiromi Kawakami hat die wahrscheinlich schönste Liebesgeschichte des Jahres geschrieben." In Welt, Die literarische Welt supplement, 21 June 2008, p. 5

Krumbholz, Martin. "Rätsel ohne Magie: Haruki Murakamis etwas überanstrengter Roman 'Afterdark." In Frankfurter Rundschau, 11 January 2006, p. 16

Kruse, Katrin. "Die dehnbare Zeit." In Tagesspiegel, 24 April 2004, p. 19

Kuhlbrodt, Detlef. "Das Existenzdurcheinander. Verzicht auf das Erhabene: In Haruki Murakamis neuem Erzählband 'Nach dem Beben' bildet das Erdbeben in Kobe 1995 den Hintergrund für viele individuelle Erschütterungen.” In taz, tazmag supplement, 8 November 2003, p. vi

Kunisch, Hans-Peter. "Und still lebt das Bügeleisen. Sehr beiläufig, sehr melancholisch, sehr eindringlich: Haruki Murakami erzählt vom Leben nach dem Beben.” In SZ, 10 October 2003, p. 16

Lenke, Kai. "Liebe in Alphaville. Gemeinsam einsam: Haruki Murakamis Roman 'Afterdark' erzählt von schlaflosen Träumen.” In Tagesspiegel, 11 January 2006, p. 21

LFD. "Hinweise auf Bücher: Erbauungsliteratur im Manga-Zeitalter." In NZZ, 3 April 2004, p. 38

Lick, Hans. "Eidechse: Kurz und Knapp.” In Welt, Die literarische Welt supplement, 4 June 2005, p. 4

Loch, Harald. "Welt ohne Heil. Kenzaburo Oe: 'Der schwarze Ast'.” In Neues Deutschland, 24 January 2003, p. 10

Loch, Harald. "Dialog mit einem Toten: Kenzaburo Oe liest beim 'internationalen Literaturfestival Berlin.'” In Neues Deutschland, 12 September 2005, p. 12

Löhndorf, Marion. 'Die Maler, das Modell, der Mord. 'Gold und Silber': Junichiro Tanizaki glaubt an die Kunst.” In NZZ, 23 December 2003, p. 35

Löhndorf, Marion. "Tod eines Freundes: Kenzaburo Oes Roman 'Tagame. Berlin-Tokyo." In NZZ, 15 September 2005, p. 37

Löhndorf, Marion. "Sanfte Melancholie und bunte Phantasie. Haruki Murakami lässt Welten aufeinander prallen." In NZZ, 21 September 2006, p. 27

Löhndorf, Marion. "Schattengleiche Stille. Manchmal zu gefällig - Haruki Murakami in zwei Erzählbänden.” In NZZ, 18 August 2007, p. 27 
Lütkehaus, Ludger. "Einstürzende Neubauten, einstürzende Biografien. Haruki Murakami erzählt mit großem Gleichmut von dem Erdbeben in Kobe." In Zeit, Literatur supplement, 9 October 2003a, p. 47

Lütkehaus, Ludger. "Mord in Matangis Schlafgemach. Ein früher kunstvoller Roman des großen Japaners Junichiro Tanizaki.” In Zeit, Literatur supplement, 13 November 2003b, p. 15

Lütkehaus, Ludger. "Leise Subversion. 'Die Geschichte einer gewissen Frau' von Chiyo Uno.” In NZZ, 9 October 2004a, p. 48

Lütkehaus, Ludger. "Frühlings Erwachen, japanisch: Ryu Murakamis umwerfend witziger Schülerroman '69."' In NZZ, 2 November 2004b, p. 37

Lütkehaus, Ludger. “Ästhetizist im Widerstand: Nagai Kafus Tagebuch von 1937.” In NZZ, 19 March 2005, p. 47

Lütkehaus, Ludger. "Das perfekte Verbrechen." In NZZ, 9 October 2006, p. 28

Lütkehaus, Ludger. "Hinweise auf Bücher. Miese Suppe.” In NZZ, 5 February 2007a, p. 28

Lütkehaus, Ludger. "Hinweise auf Bücher. Ein japanischer 'Demian'?” In NZZ, 3 December 2007b, p. 28

Lütkehaus, Ludger. "Der andere Zustand: Der japanische Kultautor Haruki Murakami über Laufen und Schreiben." In NZZ, 12 March 2008a, p. 27

Lütkehaus, Ludger. "Offener Ausgang, unschlüssiges Ende. Higuchi Ichiyo, die erste Autorin der modernen japanischen Literatur.” In NZZ, 20 May 2008b, p. 27

Lütkehaus, Ludger. "Hinweise auf Bücher. Engel, japanisch.” In NZZ, 30 June 2008c, p. 28

Lütkehaus, Ludger. "Irritierende Umarmung. Nobuo Kojimas Roman 'Fremde Familie."” In NZZ, 10 September 2008 d, p. 27

Lütkehaus, Ludger. "Hinweise auf Bücher. Im Tempel der wilden Gänse.” In NZZ, 10 November 2008e, p. 26

Lütkehaus, Ludger. “'Frühlings Erwachen' auf Japanisch. 'Mond überm Dachfirst' - ein zweiter Erzählungsband von Higuchi Ichiyo.” In NZZ, 13 December 2008f, p. 29

Magenau, Jörg. "Mit Kafkas Krähe zu den Schatten der Unterwelt: Haruki Murakami bittet Ödipus zum Sushi." In FAZ, 24 March 2004, p. 8

Mayer, Susanne. "Büchertisch. Belletristik. Chiyo Uno: Die Geschichte einer gewissen Frau." In Zeit, 9 June 2004, p. 54

Mayer, Susanne. "Belletristik. Büchertisch. Banana Yoshimoto: Sly.” In Zeit, 20 January 2005a, p. 50

Mayer, Susanne. "Belletristik. Büchertisch. Ryu Murakami: 69.” In Zeit, 20 January 2005b, p. 50

Mayer, Susanne. "Wenn der Schnee schmilzt: Der japanische Dichter Haruki Murakami nimmt uns mit auf eine 'Wilde Schafsjagd' auf der wir Vertrautes zurücklassen und uns auf einiges gefasst machen müssen.” In Zeit, 21 April 2005c, p. 53

Mensing, Kolja. "Lust auf Gewalt: Die junge japanische Autorin Akira Kuroda erzählt in ihrem Roman 'Made in Japan' von einer verlorenen Generation voller Selbstzweifel.” In taz, tazmag supplement, 12 February 2005, p. vi

Mensing, Kolja. “Tokyo Decadence. Mit 'Spiegelhölle' liegen erstmals Erzählungen des einflussreichen japanischen Kriminalschriftstellers Edogawa Rampos auf Deutsch vor.” In taz, tazmag supplement, 11 February 2006, p. vi

Messmer, Susanne. "Bewegt geborgen. Der Bruch des Bedeutsamen im Banalen oder Dostojewskis Idiot in Johnnie Walker: Haruki Murakamis wunderbarer neuer Roman 'Kafka am Strand." In $t a z, 25$ March 2004a, p. xi

Messmer, Susanne. "Mädchenton. Modernes Lesen: Kurz besprochen von Susanne Messmer. Banana Yoshimoto: 'Hard-boiled, Hard Luck.'” In taz, 27 July 2004b, p. 17 
Messmer, Susanne. "Leises Pfeifen: Modernes Lesen von Susanne Messmer.” In taz, 8 February 2005, p. 17

Messmer, Susanne. "Im Land der einsamen Großstadtwölfe. Traurige und sensible Aussteiger, Geschichten von der dunklen Seite des Mondes: Neue Romane und Erzählungen aus Japan von Hitomi Kanehara, Ryu Murakami, Hitonari Tsuji. Geschildert wird ein verunsichertes Land. Als Chef im Ring erweist sich dabei wieder einmal der Altmeister Haruki Murakami." In $t a z, 3$ January 2007a, p. 15

Messmer, Susanne. 'Ein Leben lang Tee kochen lernen. Kult der Kälte: 'Der Tod des Teemeisters' - ein Roman des japanischen Autors und Nationalheiligtums Yasushi Inoue.” In taz, tazmag supplement, 21 July 2007b, p. vi

Messmer, Susanne. "Die Genießerin und ihr Lehrer. Das Leben zwischen Futon und Izakaya, der japanischen Kneipe: 'Der Himmel ist blau, die Erde ist weiß,' und Hiromi Kawakami schreibt eine gleichmäßig dahinfließende Erzählung, die umso mehr berührt.” In taz, 13 March 2008, p. xi

Müller, Burkhard. "Unterm Fischregen. Zart, klug und jung: Haruki Murakamis 'Kafka am Strand." In SZ, 16 April 2004, p. 16

Müller, Burkhard. "Die Vollkommenheit des Unvollkommenen. Japan um 1600: Yasushi Inoues historischer Roman 'Der Tod des Teemeisters." In SZ, 6 June 2007, p. 16

Müller, Burkhard. "Die rätselhafte Torheit eines alten Mannes. Vorzeichen in großen Holzkisten: Ein Buch von Kenzaburo Ôe, an dem man das Fragen lernen kann." In SZ, 5 November 2008, p. 16

Münder, Peter. "Einsamkeit ist ein Gefängnis." In Welt, Die literarische Welt supplement, 4 June 2005 , p. 4

Neidhart, Christoph. "Nur die Schlaue überlebt. Die Wirtschaftskrise trifft in Japan nur das weibliche Geschlecht. In ihrem Bestseller 'Die Umarmung des Todes' schildert Natsuo Kirino, wie sich Frauen wehren - sie zerlegen die Männer.” In Weltwoche, 11 September 2003, p. 91

Neidhart, Christoph. "Tokios Vororte sind kein guter Platz für große Gesten und Gefühle: Hiromi Kawakamis Roman 'Der Himmel ist blau, die Erde ist weiß' erzählt von zwei seltsamen Liebenden in einer Vorstadtkneipe.” In Tagesanzeiger, 24 June 2008, p. 55

OÖ Nachrichten. "Lesestoff. Zum Entdecken," 7 July 2007, p. 48

Ortheil, Hanns-Josef. "Wo Schöne schlafen.” In Welt, Die literarische Welt supplement, 21 August 2004, p. 2

Otte, Joachim. "Risse in der Seele: Haruki Murakami spürt den Folgen des Erdbebens von Kobe nach.” In Tagesspiegel, 14 March 2004, p. 28

Patzer, Georg. “Das aktuelle Taschenbuch: Mythisch.” In Stuttgarter Zeitung, 19 March 2004, p. 35

Patzer, Georg. "Das aktuelle Taschenbuch. Juden in Kabul und die Madonna der Eisdiele." In Stuttgarter Zeitung, 12 October 2007, p. 37

Plath, Jörg. "Missratene Fingerübung. Haruki Murakamis Roman 'Afterdark.”” In NZZ, 19 January 2006, p. 27

PRAS. "Kafka grandios: Haruki Murakami." In Frankfurter Rundschau, 3 August 2007, pp. 44-45

PUH. "Hinweise auf Bücher: Keine Lust ohne Qual.” In NZZ, 31 March 2008, p. 26

Rademacher, Christina. "Ein Kafka aus Japan. Der neue Roman von Haruki Murakami ist ab Anfang März im Buchhandel: Mit 'Kafka am Strand' zielt der japanische Bestseller-Autor auf junge Leser ab. Der Held in der Liebesgeschichte heißt Kafka Tamura und ist fünfzehn Jahre alt. Er läuft von zu Hause fort, um der stärkste 15-Jährige der Welt zu werden.” In Salzburger Nachrichten, Lebensart supplement, 28 February 2004a, p. vii 
Rademacher, Christina. “Einsam erzählen.” In Salzburger Nachrichten Lebensart supplement, 28 February 2004b, p. vii

Rademacher, Christina. "Literatur von der Langstrecke: Über das Laufen. Der japanische Autor Haruki Murakami schreibt und läuft - In seinem jüngsten Buch schildert er Marathonerlebnisse." In Salzburger Nachrichten, 18 March 2008, p. 11

Radisch, Iris. "Eidechse: Belletristik. Büchertisch.” In Zeit, 21 April 2005, p. 60

Reinacher, Pia. "Macht euch locker. Der Weg ist das Ziel: Ein Frühwerk Haruki Murakamis." In FAZ, 29 November 2005, p. 36

Resch, Andreas. “Terror im Kopf. Kenzaburo Oes Roman übers Schreiben nach 9/11.” In Tagesspiegel, 31 October 2008, p. 26

Rubinowitz, Tex. "Starbucks auf Japanisch: Nippon Peter Carey wundert sich über Japan, Kenzaburo Oe muss das nicht - er stammt von dort und begibt sich nach Berlin." In Falter, Buchbeilage supplement, 21 October 2005, p. 33

Rühle, Alex. "Das Gift der Seele, das nach oben steigt. Immer bleibt das Laufen aufs Schreiben ausgerichtet: Der Schriftsteller Haruki Murakami als Langstreckenläufer.” In SZ, 29 February 2008, p. 14

Schneider, Markus B. "Radikale Sehnsucht: In 'Afterdark' lässt Haruki Murakami die Helden wieder durch seine Welt streunen - jetzt noch nackter." In Weltwoche, 1 December 2005, pp. $82-83$

Schoettli, Urs. "Krimi und Kritik: Natsuo Kirinos 'Umarmung des Todes."' In NZZ, 12 August 2003, p. 35

Scholz, Leander. "Tod in Ägypten. Pubertätstagebuch: In ihrem neuen Roman 'Sly' scheitert Banana Yoshimoto an den letzten Dingen.” In Freitag, 11 July 2003, p. 14

Schuh, Franz. "Freudenhaus für Greise." In Zeit, 21 October 2004, p. 60

Schulz, Gerhard. "Am Tempellimit. Missionarisch: Kenzaburo Oe beendet seine Trilogie des Protests.” In FAZ, 30 October 2003, p. 34

Schütt, Hans-Dieter. "Lebens Lauf: Anlässlich von Haruki Murakamis Buch zur MarathonExistenz." In Neues Deutschland, 14 July 2008, p. 12

Seiler, Christian. "Kafka zum Anfassen: Mit seinem neuesten Roman gelingt Haruki Murakami ein weiterer Bestseller. Weshalb sind seine absurden Geschichten so erfolgreich?" In Weltwoche, 22 April 2004, pp. 80-82

SER. "Bücher in Kürze. Laufender Literat." In Wiener Zeitung, extra supplement, 23 August 2008, p. 11

Sojitrawalla, Shirin. "Hübsche, trostlose Melancholie. Tokio in Slowmotion: 'Afterdark' von Haruki Murakami.” In Wiener Zeitung, extra supplement, 9 December 2005, p. 10

Sperl, Ingeborg. "Lust, Tod und Schweinesauce. Natsuo Kirinos preisgekrönter Thriller über den Zorn japanischer Frauen.” In Standard, Album supplement, 21 June 2003, p. 7

Spinnen, Burkhard. "Das universelle 'Du darfst': Haruki Murakamis Roman 'Hard-Boiled Wonderland und das Ende der Welt."' In SZ, 16 May 2006, p. 16

Staude, Sylvia. "Das Gift ausschwitzen. 'Wovon ich rede, wenn ich vom Laufen rede': Haruki Murakami hat eine ganz spezielle Autobiografie geschrieben." In Frankfurter Rundschau, Literatur Rundschau supplement, 11 March 2008a, p. 14

Staude, Sylvia. "Brüder im Verbrechen. Arimasa Osawas Krimi-Reihe 'Der Hai von Shinjuku' erzählt von der Polizeiarbeit im dunklen Herzen Tokios." In Frankfurter Rundschau, 27 March 2008b, p. 38

Stift, Linda. "Ungefährliche Geister: Neue Erzählungen von Banana Yoshimoto.” In Wiener Zeitung, 16 July 2004, p. 9 
Strobl, Sabine. "Die Krähe in der Unterwelt: Haruki Murakami hat mit 'Kafka am Strand' ein fantastisches Buch über einen 15-Jährigen und dessen Abenteuer geschrieben." In Tiroler Tageszeitung, Magazin supplement, 29 May 2004, p. 6

Stüttgen, Tim. "Weitermachen.” In Wochenzeitung, 9 October 2003, p. 18

Taschwer, Klaus. 'Die Leiden des jungen K. Literatur, 'Kafka am Strand,' die neue Schwarte des japanischen Kultautors Haruki Murakami, handelt von der abenteuerlichen Selbstfindung eines ziemlich starken 15-Jährigen - und festigt den guten Ruf seines Autors.” In Falter, 5 March 2004, p. 64

Tauber, Reinhold. "Blick durch den Schleier: Ein berühmter japanischer Filmregisseur stürzt sich von einem Hochhaus in den Freitod. Ein berühmter japanischer Romancier - Schwager und Freund des Regisseurs - erhält eine Menge Tonkassetten, besprochen vom Regisseur vor dessen Tod." In OÖ Nachrichten, 15 February 2006, p. 14

taz. "Bücher aus den Charts. Zauberhafte Dialoge: Haruki Murakamis neuer Roman 'Afterdark." In taz, tazmag supplement, 14 January 2006, p. vi

Teuffel, Friedhard. "Freier Kopf: Haruki Murakamis Buch über das Laufen.” In Tagesspiegel, 4 May 2008, p. 28

Thuswaldner, Anton. "Der stille Mahner.” In Salzburger Nachrichten, 24 September 2005, p. 16

Thuswaldner, Anton. "Hard-Boiled Wonderland.” In Salzburger Nachrichten, Lebensart supplement, 1 July 2006, p. vi

TILL. "Kritik in Kürze: Monstergeschichten.” In FAZ, 4 February 2008, p. 34

Timmerberg, Helge. "Gott ist ein Herr aus Tokyo: Haruki Murakami erzählt und erzählt und erzählt, das ist wie Sadismus oder wie Buddhismus oder sonst wie - auf jeden Fall ist es Weltliteratur." In Zeit, Literatur supplement, 1 September 2006, p. 22

Vorarlberger Nachrichten. "Farbenfrohe Skizze einer Freundschaft: Der Sprachrhythmus ist der Protagonist des neuen Romans von Kenzaburo Oe," 3 September 2005a, p. 4

Vorarlberger Nachrichten. "Das Fantastische: Neue Rätsel von Japans Erfolgsautor Haruki Murakami für deutsche Leser," 26 November 2005b, p. 6

Wedler, Patricia. "Brutal moralisch." In Wochenzeitung, 13 January 2005, p. 18

Weissmüller, Laura. "Die Prismen funkeln. Viel wertvoller als tagsüber: Banana Yoshimotos 'Eidechse."' In SZ, 4 August 2005, p. 14

Welle, Florian. "Ekelwut und Schneefall: Yôko Ogawas kalte Präzision.” In SZ, Literatur supplement, 9 October 2007, p. 4

Wellershoff, Marianne. "Auf der Suche nach dem eigenen Ich: Der Japaner Haruki Murakami schildert die surrealen Abenteuer eines Teenagers auf dem Weg ins Erwachsenenleben.” In Spiegel, 22 March 2004, pp. 191-192

Wiegandt, Kai. "Vom Merkwürdigwerden und Seltsambleiben der Welt. Für alles gibt es eine seltsam logische Erklärung: Haruki Murakamis Erzählungen 'Der Elefant verschwindet.”' In SZ, 17 January 2008, p. 14

Willmann, Urs. "Er war so freundlich: Seit 25 Jahren pflegt Haruki Murakami eine zweite Leidenschaft. Er rennt Marathons. Jetzt hat sich der Romanautor dazu hinreißen lassen, übers Laufen zu schreiben.” In Zeit, Literatur supplement, 13 March 2008, p. 35

Winkels, Hubert. "Tote Zonen im lebendigen Alltag: Yoko Ogawa erzählt von weiblicher Selbstauslöschung.” In Zeit, 17 July 2003, p. 42

Winkels, Hubert. "Ein Parzival aus Japan: Warum 'Hard-boiled Wonderland und Das Ende der Welt' Haruki Murakamis bester Roman ist.” In Zeit, 27 April 2006, p. 52

Winkels, Hubert. "Liebe in Zeiten der Kirschblüte. Hiromi Kawakamis Roman 'Der Himmel ist blau, die Erde ist weiß’ stellt alles infrage, was wir von Männern und Frauen wissen.” In Zeit, 21 May 2008, pp. 53-54 
Wörtche, Thomas. “Crime Watch N 129.” In Freitag, 25 January 2008, p. 16

WP. 'Geisterstunden. Mühselige Reise durch die Nacht: 'Afterdark,' der neue Roman des japanischen Starautors Haruki Murakami.” In Profil, 14 November 2005, p. 133

WRK. “Applaus. Thriller.” In Welt, 19 October 2006, p. 67

Zier, O. P. "Es regnet Fische und Blutegel. Eine Mixtur aus Volksaberglauben und Trivialmythen, verbunden mit Lesefrüchten aller Art und Versatzstücken aus der Konsumwelt: Haruki Murakamis Roman 'Kafka am Strand.'” In Presse, Spectrum supplement, 6 March 2004, p. 5

\section{Reviewed Works}

Only the versions referred to in the review articles are listed, not previous issues or later reissues.

Akutagawa, Ryūnosuke 芥川龍之介. Dialoge in der Dunkelheit: Späte Prosa und Erzählungen. Translated by Armin Stein. München: Iudicium, 2003

Edogawa, Rampo 江戸川乱歩. Spiegelhölle: Acht Erzählungen, J-Book series. Translated by Martina Berlin et al. Berlin: Maas, 2005

Gen’yû, Sôkyû 玄侑宗久. Das Fest des Abraxas [Aburakusasu no matsuri アブラクサスの祭 (2001)], Japan Edition series. Translated by Liesette Gebhardt. Berlin: Bebra, 2007

Higashino, Keigo 東野圭吾. Mord am See [Reikusaido レイクサイド (2002)]. Translated by Katja Busson. Löhne: Cass, 2003

Higuchi, Ichiyō 樋口一葉. In finsterer Nacht und andere Erzählungen. Translated by Michael Stein. München: Iudicium, 2007

Higuchi, Ichiyo. Mond überm Dachfirst: Erzählungen, Bibliothek der Weltliteratur series. Translated by Michael Stein. Zürich: Manesse, 2008

Ikezawa, Natsuki 池澤夏樹. Aufstieg und Fall des Macias Guili [Mashiasu Giri no shikkaku マシ アスギリの失脚 (1993)], Japan Edition series. Translated by Otto Putz. Berlin: Bebra,

Inoue, Yasushi 井上靖. Der Tod des Teemeisters [Honkakubō-ibun 本覚坊遺文 (1981)]. Translated by Ursula Gräfe. Frankfurt a.M.: Suhrkamp, 2007

Kaga, Otohiko 加賀乙彦. Kreuz und Schwert. Roman über die Christenverfolgung in Japan [Takayama Ukon 高山右近 (1999)], Japan Edition series. Translated by Ralph Degen. Berlin: Bebra, 2006

Kanehara, Hitomi 金原ひとみ. Tokyo Love [Hebi ni piasu 蛇にピアス (2003)]. Translated by Sabine Mangold. Berlin: List, 2006

Kawabata, Yasunari 川端康成. Die schlafenden Schönen [Nemureru bijo 眠れる美女 (19601961)]. Translated by Siegfried Schaarschmidt. Frankfurt a.M.: Suhrkamp, 2004a

Kawabata, Yasunari. Schneeland [Yukiguni 雪国 $(1935 / 1937,1947)]$. Translated by Tobias Cheung. Frankfurt a. M.: Suhrkamp, 2004b

Kawakami, Hiromi 川上弘美. Der Himmel ist blau, die Erde ist weiß. Eine Liebesgeschichte [Sensei no kaban センセイの鞄 (2001)]. Translated by Ursula Gräfe and Kimiko NakayamaZiegler. München: Hanser, 2008

Kirino, Natsuo 桐野夏生. Die Umarmung des Todes [Out (=Auto) アウト(1997)]. Translated by Annelie Ortmanns. München: Goldmann, 2003

Kojima, Nobuo 小島信夫. Fremde Familie [Hōyo kazoku 抱擁家族 (1965)], Japan Edition series. Translated by Ralph Degen. Berlin: Bebra, 2008

Kurahashi, Yumiko 倉橋由美子. Die Reise nach Amanon [Amanon-koku ōkankiアマノン国往還 記 (1986)], Japan Edition series. Translated by Monika Wernitz-Sugimoto and Hiroshi Yamane. Berlin: Bebra, 2006

Kuroda, Akira 黒田晶. Made in Japan [Meido in Japan メイドインジャパン (2001)], J-Book series. Translated by Martina Berlin. Berlin: Maas, 2004 
Mizukami, Tsutomu 水上勉. Im Tempel der Wildgänse [Gan no tera 雁の寺 (1961)], Japan Edition sereis. Translated by Verena Werner. Berlin: Bebra, 2008

Murakami, Haruki 村上春樹. Mister Aufziehvogel [Nejimaki dori kuronikuru ねじまき鳥クロニ クル (1994-1995)], vol. 72668 of btb. Translated by Giovanni and Ditte Bandini [from the English The Wind-up Bird Chronicle (1997)]. Köln: Goldmann, 2000

Murakami, Haruki. Nach dem Beben: Erzählungen. Translated by Ursula Gräfe. Köln: Dumont, $2003 \mathrm{a}$

Murakami, Haruki. Sputnik Sweetheart [Supūtoniku no koibito スプートニクの恋人 (1999)]. Translated by Ursula Gräfe. Köln: Dumont, 2003b

Murakami, Haruki. Tanz mit dem Schafsmann [Dansu, dansu, dansu ダンス ダンス ダンス (1988)]. Translated by Sabine Mangold. Köln: btb, 2003c

Murakami, Haruki. Wilde Schafsjagd [Hitsuji o meguru bōken 羊をめぐる冒険 (1982)], vol. 2738 of suhrkamp taschenbuch. Translated by Annelie Ortmanns-Suzuki and Jürgen Stalph. Frankfurt a.M.: Suhrkamp, 2003d

Murakami, Haruki. Kafka am Strand [Umibe no Kafuka 海辺のカフカ (2002)]. Translated by Ursula Gräfe. Köln: Dumont, 2004

Murakami, Haruki. Afterdark [Afutādākuアフターダーク (2004)]. Translated by Ursula Gräfe. Köln: Dumont, 2005a

Murakami, Haruki. Tony Takitani [Tonī Takitani トニー滝谷 (1990)]. Translated by Ursula Gräfe. Köln: Dumont, 2005b

Murakami, Haruki. Blinde Weide, schlafende Frau: Erzählungen. Translated by Ursula Gräfe. Köln: Dumont, 2006a

Murakami, Haruki. Frosch rettet Tokyo: Erzählungen. Translated by Ursula Gräfe. Köln: Dumont, $2006 \mathrm{~b}$

Murakami, Haruki. Hard-boiled wonderland und das Ende der Welt [Sekai no owari to hādoboirudo-wandārando 世界の終わりとハードボイルドワンダーランド (1985)]. Translated by Annelie Ortmanns. Köln: Dumont, 2006c

Murakami, Haruki. Der Elefant verschwindet. Erzählungen. Translated by Nora Bierich. Köln: Dumont, 2007a

Murakami, Haruki. Wie ich eines schönen Morgens im April das 100\%ige Mädchen sah: Erzählungen. Translated by Ursula Gräfe. Köln: Dumont, 2007b

Murakami, Haruki. Wovon ich rede, wenn ich vom Laufen rede [Hashiru koto ni tsuite kataru toki ni boku no kataru koto 走ることについて語るときに僕の語ること (2007)]. Translated by Ursula Gräfe. Köln: Dumont, 2008

Murakami, Ryu 村上龍. 69 [69 (1987)], vol. 3633 of suhrkamp taschenbuch. Translated by Andrea Viala [from English 69 (1993)]. Frankfurt a.M.: Suhrkamp, 2004

Murakami, Ryu. In der Misosuppe [In za miso sūpu インザミソスープ (1979)]. Translated by Ursula Gräfe. Köln: Kiepenheuer \& Witsch, 2006

Nagai, Kafû 永井荷風. Tagebuch: Das Jahr 1937 [Danchōtei nichijō 断腸亭日乗 (1917/1939)]. Translated by Barbara Yoshida-Krafft. München: Iudicium, 2003

Ōe, Kenzaburō 大江健三郎. Der atemlose Stern [Ōi naru hi ni 大いなる日に (1995)]. Translated by Nora Bierich. Frankfurt a.M.: Fischer, 2003

Ōe, Kenzaburō. Der stumme Schrei [Manen gannen no futtobōru 万延元年のフットボール (1967)]. Translated by Ingrid and Rainer Rönsch [from English The Silent Cry (1974)]. Frankfurt a.M.: Fischer, 2005a

Ōe, Kenzaburō. Tagame: Berlin-Tokyo [Torikaeko/Chenjiringu 取り替え子/チェンジリング (2000)]. Translated by Nora Bierich. Frankfurt a.M.: Fischer, 2005b 
Ōe, Kenzaburō. Sayonara, meine Bücher [Sayōnara, watashi no hon yo! さようなら、私の本よ! (2005)]. Translated by Nora Bierich, Frankfurt a.M.: Fischer, 2008

Ogawa, Yôko 小川洋子. Schwimmbad im Regen: Erzählungen. Translated by Ursula Gräfe and Kimiko Nakayama-Ziegler. München: Liebeskind, 2003

Ogawa, Yôko. Liebe am Papierrand [Yohaku no ai 余白の愛 (1991)]. Translated by Ursula Gräfe and Kimiko Nakayama-Ziegler. München: Liebeskind, 2004

Ogawa, Yôko. Das Museum der Stille [Chinmoku hakubutsukan 沈黙博物館 (2000)]. Translated by Ursula Gräfe and Kimiko Nakayama-Ziegler. München: Liebeskind, 2005a

Ogawa, Yôko. Hotel Iris [Hoteru Airisu ホテルアイリス (1996)]. Translated by Ursula Gräfe and Kimiko Nakayama-Ziegler. München: dtv, 2005b

Ogawa, Yôko. Der zerbrochene Schmetterling: Erzählungen. Translated by Ursula Gräfe and Kimiko Nakayama-Ziegler. München: Liebeskind, 2007

Osawa, Arimasa (=Ōsawa Arimasa) 大沢在昌. Der Hai von Shinjuku: Sodom und Gomorra [Shinjuku-zame 新宿鮫 (1990)]. Translated by Katja Busson. Löhne: Cass, 2005

Osawa, Arimasa. Der Hai von Shinjuku. Rache auf Chinesisch [Shinjuku-zame II: Dokuzaru 新宿 鮫 II 毒猿 (1991)]. Translated by Katja Busson. Löhne: Cass, 2007

Tanikawa, Shuntarô 谷川 俊太郎. Fels der Engel. Zu Zeichnungen von Paul Klee [Kuree no tenshi Pauru Kuree-e クレーの天使 パウル・クレー絵 (2000)], vol. 21 of Waldgut Lektur. Translated by Eduard Klopfenstein. Frauenfeld: Waldgut, 2008

Tanizaki, Jun'ichirō 谷崎潤一郎. Lob des Schattens [In'ei raisan 陰笌礼讃 (1933)]. Translated by Eduard Klopfenstein. Zürich: Manesse, 2002

Tanizaki, Junichiro (=Tanizaki Jun'ichirō). Gold und Silber [Kin to gin 金と銀 (1918)]. Translated by Uwe Hohmann and Christian Uhl. Leipzig: Reclam, 2003

Tsuji, Hitonari 辻仁成. Warten auf die Sonne [Taiyō machi 太陽待ち (2001)]. Translated by Ursula Gräfe and Kimiko Nakayam-Ziegler. München: Piper, 2006

Tsutsui, Yasutaka 筒井康隆. Mein Blut ist das Blut eines anderen [Ore no chi wa tanin no chi お れの血は他人の血. (1972-1973)], Japan ed. Translated by Otto Putz. Berlin: Bebra, 2006

Uno, Chiyo 宇野千代. Die Geschichte einer gewissen Frau [Aru hitori no onna no hanashi 或る 一人の女の話 (1971)], vol. 3607 of suhrkamp taschenbuch. Translated by Barbara YoshidaKrafft. Frankfurt a.M.: Suhrkamp, 2004

Yamada, Taichi 山田 太一. Sommer mit Fremden [Ijin-tachi to no natsu 異人たちとの夏 (1987)]. Translated by Ursula Gräfe and Kimiko Nakayama-Ziegler. München: Goldmann, 2007

Yoshimoto, Banana よしもとばなな. Hard-boiled, Hard Luck. Zwei Erzählungen [Hādoboirudo/Hādorakkuハードボイルド/ハードラック (1999)]. Translated by Annelie Ortmanns. Zürich: Diogenes, 2004a

Yoshimoto, Banana. Sly [Sly (1996)]. Translated by Anita Brockmann. Zürich: Diogenes, 2004b

Yoshimoto, Banana. Eidechse: Erzählungen [Tokage とかげ (1993)]. Translated by Anita Brockmann and Annelie Ortmanns. Zürich: Diogenes, 2005

Yoshimoto, Banana. Federkleid [Hagoromo ハゴロモ (2003)]. Translated by Thomas Eggenberg. Zürich: Diogenes, 2007

Yoshimura, Akira 吉村昭. Unauslöschlich [Karishakuhō 仮釈放 (1988)]. Translated by Sabine Mangold. München: btb, 2004

\section{Secondary Sources}

BBZ (=Buch und Buchhandel in Zahlen): Börsenverein des Deutschen Buchhandels e.V. Buch und Buchhandel in Zahlen. Frankfurt a. M.: Buchhändlervereinigung, 2000 
BBZ: Börsenverein des Deutschen Buchhandels e.V. Buch und Buchhandel in Zahlen. Frankfurt a.

M.: Buchhändlervereinigung, 2001

BBZ: Börsenverein des Deutschen Buchhandels e.V. Buch und Buchhandel in Zahlen. Frankfurt a.

M.: Buchhändlervereinigung, 2002

BBZ: Börsenverein des Deutschen Buchhandels e.V. Buch und Buchhandel in Zahlen 2003.

Frankfurt a. M.: Marketing- und Verlagsservice des Buchhandels, 2003

BBZ: Börsenverein des Deutschen Buchhandels e.V. Buch und Buchhandel in Zahlen 2004.

Frankfurt a. M.: Marketing- und Verlagsservice des Buchhandels, 2004

BBZ: Börsenverein des Deutschen Buchhandels e.V. Buch und Buchhandel in Zahlen 2005.

Frankfurt a. M.: Marketing- und Verlagsservice des Buchhandels, 2005

BBZ: Börsenverein des Deutschen Buchhandels e.V. Buch und Buchhandel in Zahlen 2006.

Frankfurt a. M.: Marketing- und Verlagsservice des Buchhandels, 2006

BBZ: Börsenverein des Deutschen Buchhandels e.V. Buch und Buchhandel in Zahlen 2007.

Frankfurt a. M.: Marketing- und Verlagsservice des Buchhandels, 2007

BBZ: Börsenverein des Deutschen Buchhandels e.V. Buch und Buchhandel in Zahlen 2008.

Frankfurt a. M.: Marketing- und Verlagsservice des Buchhandels, 2008

BBZ: Börsenverein des Deutschen Buchhandels e.V. Buch und Buchhandel in Zahlen 2009.

Frankfurt a. M.: Marketing- und Verlagsservice des Buchhandels, 2009

Giacomuzzi-Putz, Renate. "Die japanische Literatur in deutschsprachigen Printmedien." In

Interkulturelle Perspektiven Japan: Deutschland, edited by Deutsches Institut für Japanstudien.

München: Iudicium, 1996, pp. 153-182

Havranek, Erich. "Atmosphäre ohne Exotik: Vermittlung japanischer Literatur im deutschen

Sprachraum.” In Streifzüge im translatorischen Feld zur Soziologie der literarischen Überset-

zung im deutschsprachigen Raum, edited by Michaela Wolf and Norbert Bachleitner. Wien:

Lit, 2010, pp. 293-316

Hijiya-Kirschnereit, Irmela. "Nintendō-Oper und Bonsai-Geschichten: Zur aktuellen Rezeption japanischer Literatur im deutschen Sprachraum." In Blickwinkel: Kulturelle Optik und interkulturelle Gegenstandskonstitution. Akten des III. internationalen Kongresses der Gesellschaft für Interkulturelle Germanistik, Düsseldorf 1994, edited by Alois Wierbacher and Georg Stötzl. München: Iudicium, 1996, pp. 701-713

Hijiya-Kirschnereit, Irmela. "Prügel für den Elöser. Aber die Schuld trifft den Autor: Ōes neuer Roman.” In FAZ, 7 February 2001, p. 50

Ogasa, Gisela, Dörte Puls, and Jürgen Stalph. Moderne japanische Literatur in deutscher Übersetzung: Eine Bibliographie der Jahre 1868-1994. München: Iudicium, 1995

Schmuck, Judith. "Die Rezeption Murakami Harukis in deutschsprachigen Printmedien.” M.A. thesis, University of Vienna, 2005

Spiegel, Hubert. "Japanische Literatur im deutschen Feuilleton." In Eine gewisse Farbe der

Fremdheit: Aspekte des Übersetzens Japanisch-Deutsch-Japanisch, edited by Irmela HijiyaKirschnereit. München: Iudicium, 2001, pp. 89-98

Worm, Herbert. "Haruki Murakami: Die Wahrheit über den Reich-Ranicki-Skandal.” In FAZ, 5 August 2000, n.p. 


\section{GLOSSARY}

Abe Kōbō
Afutā Dāku
Akutagawa Ryūnosuke
Amanon-koku ōkanki
Anchū mondō
Aru hitori no onna no
hanashi
Auto [=Out]

Bungakukai

Bungeishunjū

Bunka-chō
Chinmoku-hakubutsukan
Edogawa Ranpo
Endō Shūsaku
Gan no tera
Hagoromo

安部公房

アフターダーク

芥川龍之介

アマノン国往還記

闇中問答

或る一人の女の話

アウト

文學界

文化庁

沈墨博物館

江戸川乱歩

遠藤周作

雁の寺

ハゴロモ

author, 1924-93

novel by Murakami Haruki

author, 1892-1927

novel by Kurahashi Yumiko

dialog by Akutagawa Ryūnosuke

novel by Uno Chiyo

'Auto' is the Japanese transliteration of the English title Out of the Japanese novel by Kirino Natsuo provided on the title page to clarify pronunciation Literary World; name of two monthly literary magazines. The first one was published from 1893 until 1895. Another one was founded in 1933 and after a change of ownership in 1938 continues publication to today.

Literary Spring and Autumn; monthly general interest magazine, founded in 1923 as a literary magazine.

Agency for Cultural Affairs novel by Ogawa Yōko author, 1894-1965 author, 1923-96 novel by Mizukami Tsutomu novel by Yoshimoto Banana memoir by Murakami Haruki

Hashiru koto ni tsuite kataru 走ることについて語るとき toki ni boku no kataru koto に僕の語ること

Hebi ni piasu

Higashino Keigo

Higuchi Ichiyō

Honkakubō-ibun

Ikezawa Natsuki

Inoue Yasushi

In za miso sūpu

Isetan

Itami Jūzō

Kanehara Hitomi

Karishakuhō

Kawabata Yasunari

Kawakami Hiromi

Kirino Natsuo

Kokkyō no minami, taiyō no nishi

Kokusai Kōryū Kikin

Kurahashi Yumiko
蛇にピアス

東野圭吾

樋口一葉

本覚坊遺文

池澤夏樹

井上靖

インザミソスープ

伊勢丹

伊丹十三

金原ひとみ

仮釈放

川端康成

川上弘美

桐野夏生

国境の南、太陽の西

国際交流基金

倉橋由美子 novel by Kanehara Hitomi

author, 1958-

author, 1872-96

novel by Inoue Yasushi

author, 1945-

author, 1907-91

novel by Murakami Ryū

a Japanese department store

actor, film director, 1933-97

author, 1983-

novel by Yoshimura Akira

author, 1899-1972

author, 1958-

author, 1951-

novel by Murakami Haruki

Japan Foundation

author, 1935-2005 
Kuroda Akira

Meido in Japan

"Mekura yanagi to nemuru onna"

Mishima Yukio

Mizukami Tsutomu

Murakami Haruki

Murakami Ryū

Nagai Kafū

Ninshin-karendā

Noruwei no mori

Ōe Kenzaburō

Ogawa Yōko

Ore no chi wa tanin no chi

Ōsawa Arimasa

Reikusaido

Sayōnara, watashi no hon yo!

Sensei no kaban

"Shigatsu no aru hareta asa ni 100-pāsento no onna no ko ni deau koto ni tsuite"

Shinjuku zame

Shinjuku-zame II: Dokuzaru shishōsetsu

Taiyō machi

Tanizaki Jun'ichirō

Tokage

Torikaeko/Chenjiringu

Torefuru
黒田晶

メイドインジャパン

めくらやなぎと眠る女

三島由紀夫

水上勉

村上春樹

村上龍

永井荷風

妊娠カレンダー

ノルウェイの森

大江健三郎

小川洋子

おれの血は他人の血

大沢在昌

レイクサイド

さようなら、私の本よ!

センセイの鞄

四月のある晴れた朝に 100 パーセントの女の子に出会

うことについて

\section{新宿鮫}

新宿鮫 II: 毒猿

私小説

太陽待ち

谷崎潤一郎

とかげ

取り替え子/チェンジリング novel by Ōe Kenzaburō author, 1977-

novel by Kuroda Akira

story by Murakami Haruki

author, 1925-70

author, 1919-2004

author, 1949-

author, 1952-

author, 1879-1959

story and title of a collection of stories

by Ogawa Yōko

novel by Murakami Haruki

author, 1931-

author, 1962-

novel by Tsutsui Yasutaka

author, 1956-

novel by Higashino Keigo

novel by Ōe Kenzaburō

novel by Kawakami Hiromi

story by Murakami Haruki

novel series and first part of the series by

Ōsawa Arimasa

novel by Ōsawa Arimasa

'I' novel; novel based on the authors's own life

novel by Tsuji Hitonari

author, 1886-1965

story and title of a collection of stories

by Yoshimoto Banana
Trefoil; promotional magazine of the Isetan department store, which was not sold publicly but sent to members of a club of sponsors once a month. It published a series of short stories by Murakami Haruki between 1981-83 author, 1959author, 1934woodblock print, pictures of the floating world

novel by Murakami Haruki

author, 1897-1996

story by Higuchi Ichiyō

author, 1964-

author, 1927-2006
辻仁成

筒井康隆

浮世絵

海辺のカフカ

宇野千代

闇（やみ）夜

よしもとばなな

吉村昭 
"Yūgure no kyūshokushitsu to ame no pūru"

Zō no shōmetsu
夕暮れの給食室と雨のプー story by Ogawa Yōko ル 象の消滅 story and title of a collection of stories by Murakami Haruki 